\title{
Quaternary geology of part of the McLeod Lake map-area (NTS 093J), central British Columbia: lithostratigraphy, glacial history, and chronology
}

\begin{tabular}{|r|l|}
\hline Journal: & Canadian Journal of Earth Sciences \\
\hline Manuscript ID & cjes-2016-0198.R2 \\
\hline Manuscript Type: & Article \\
\hline Date Submitted by the Author: & $31-$ May-2017 \\
\hline Complete List of Authors: & $\begin{array}{l}\text { Sacco, David; Simon Fraser University, Department of Earth Sciences; } \\
\text { Palmer Environmental Consulting Group, Inc. } \\
\text { Ward, Brent; Department of Earth Sciences } \\
\text { Lian, Olav B.; Department of Geography, } \\
\text { Maynard, Denny; Denny Maynard \& Associates Ltd. } \\
\text { Geertsema, Marten; BC Forest Service }\end{array}$ \\
\hline $\begin{array}{r}\text { Is the invited manuscript for } \\
\text { consideration in a Special } \\
\text { Issue? : }\end{array}$ & N/A \\
\hline Keyword: & $\begin{array}{l}\text { Quaternary geology, Glacial history, Central British Columbia, Chronology, } \\
\text { Stratigraphy }\end{array}$ \\
\hline &
\end{tabular}


1 Quaternary geology of part of the McLeod Lake map-area (NTS 093J), central British

2 Columbia: lithostratigraphy, glacial history, and chronology

3 David A. Sacco, Department of Earth Sciences, Simon Fraser University, Burnaby, BC.

$4 \quad$ david@pecg.ca ${ }^{1}$

5 Brent C. Ward, Department of Earth Sciences, Simon Fraser University, Burnaby, BC.

6 bcward@sfu.ca

7 Olav B. Lian, Department of Geography and the Environment, University of the Fraser Valley,

$8 \quad$ Abbotsford, BC. olav.lian@ufv.ca

9 Denny E. Maynard, Denny Maynard \& Associates Ltd., North Vancouver, BC.

10 Dmaynard\&assoc@telus.net

11 Marten Geertsema, BC Ministry of Forest and Range, Prince George, BC.

12 Marten.geertsema@gov.bc.ca

15 Corresponding Author: D.Sacco, 470 Granville St. Suite 630, Vancouver, BC, V6C 1V5; phone 16778689 2721; email - david@pecg.ca

\footnotetext{
${ }^{1}$ Current Affiliation: Palmer Environmental Consulting Group Inc. Vancouver, BC.
} 


\section{Abstract}

During the last (Fraser) glaciation, the coalescence and subsequent divergence of glaciers near the McLeod Lake map-area is recorded by landforms, ice-flow indicators and the distribution of sediments. Ice initially flowed into the study area from the northwest with at least one fluctuation in the ice-front position. Ice-flow during glacial maximum was generally to the northeast and transitioned to the east during deglaciation. The Quaternary stratigraphic record spans the Fraser Glaciation and is represented by a sequence of advance glaciolacustrine sediments, multiple till units, retreat glaciolacustrine and glaciofluvial sediments and associated post-glacial aeolian material. The surficial geology is dominated by thick, streamlined till that thins where relief is high. Glaciofluvial outwash occurs mostly in northeast and southeast trending meltwater channels, while ice-contact glaciofluvial deposits and ablation till occur in depressions throughout the region. Extensive glaciolacustrine deposits blanket low-lying regions in the southern parts of the study area. Meltwater and ice-flow features suggest that deglaciation in the region was dominantly frontal retreat and that ice was largely active as it retreated through the study area. Post-glacial aeolian activity was brief; optical dating on K-feldspar from aeolian landforms indicate that they had stabilized by between $8.71-10.71$ and $12.3-14.3 \mathrm{ka}$, and provide minimum ages for ice retreat. The data from the study area are evaluated with similar data from adjacent regions to develop an ice-flow history, and refine the conceptual model of deglaciation for the northern Interior Plateau. 
39 The McLeod Lake map-area, National Topographic System (NTS) 093J, in central British

40 Columbia is situated near the geographic centre of the Cordilleran Ice Sheet (CIS); here glaciers

41 from the Coast, Skeena, Omineca, and Cariboo mountains coalesced, creating a dynamic glacial

42 environment that has previously only been described in limited detail (Tipper 1971a, $b$ ). The

43 region is characterized by thick drift consisting of sediments and landforms of the Fraser

44 Glaciation allowing a record of glacial events to be determined. Mineral exploration in the region

45 has been limited by the thick drift and infrequent, isolated bedrock exposures. Techniques that

46 utilize glacial deposits, such as till geochemical and mineralogical surveys, are best suited to

47 these environments (Bobrowsky et al. 1995; McClenaghan et al. 2000). Increased mineral

48 exploration interest in this area has necessitated a more detailed understanding of glaciation and

49 its impact on the landscape to plan, execute and interpret these surveys and to provide resources

50 for development.

51 The objective of this paper is to provide an overview of the surficial geology and Quaternary

52 history of the study area, and suggest some regional-scale implications for the understanding of

53 the Fraser Glaciation in central British Columbia. The glacial history of the area is based on the

54 distribution of surficial materials and landforms, lithostratigraphy, and geochronology. The

55 interpretations are extended into adjacent map sheets NTS 093F/G/K and /O (Figure 1), and used

56 to propose a model for deglaciation in the region that provides insight into the growth and decay

57 of the CIS.

58 Previous Studies 
59 Only reconnaissance Quaternary work has been done in the McLeod Lake map area (Armstrong 60 and Tipper, 1948; Tipper, 1971 $a, b$ ); however, detailed studies have been conducted in adjacent

61 regions. Regional glacial landform mapping was completed at 1:250 000 scale by Tipper

62 (1971a). Prior to the flooding of the Williston reservoir to the north, Rutter $(1974 a, b)$ mapped

63 the surficial geology and landforms, and documented stratigraphic data from the Peace, Parsnip

64 and Finlay rivers (Rutter 1977). This was furthered with additions to understanding of the

65 stratigraphic record by Bobrowsky and Rutter (1992). Hickin et al., (2015, 2016) discuss

66 stratigraphy, ice dynamics and deglacial geomorphology around the Peace River, east of the

67 Rocky Mountains. Kerr (1991) carried out surficial geology studies of the Mount Milligan area

68 that straddles the east and west sides of map area NTS 093N/1 and 093O/4, respectively. Glacial

69 history has been discussed south of the study area in parts of map sheets NTS 093A/B/G and /H

70 by Clague (1988), Clague et al. (1990), and Levson et al. (1990); in the west and northwest

71 adjacent map sheets NTS 093K/N by Plouffe (1992, 1997, 2000), Plouffe and Williams (1998),

72 and Stumpf et al. (2000); about $125 \mathrm{~km}$ west in parts of map sheets NTS 093L/M by Levson

73 (2001); and to the southwest in the northern part of map sheet NTS 093F Levson et al. (1998),

74 Mate and Levson (2001), and Plouffe and Levson (2001a,b). For a comprehensive review of

75 previous Quaternary studies and their extents see Sacco (2012).

76 Physiography

77 The study area lies within the Interior Plateau of the Canadian Cordillera and includes parts of

78 the Fraser Basin, Nechako Plain and Nechako Plateau physiographic subregions (Holland 1976).

79 The majority of the study area is within the Fraser Basin and Nechako Plain, which are

80 characterized by moderate to low relief between 675 and $1000 \mathrm{~m}$ above sea level (m a.s.1.).

81 Surficial deposits are thick enough to mask most bedrock topography, and bedrock exposures are 
82 rare. The northwestern part of the study area is within the Nechako Plateau. Here, the southern

83 portion of the Wolverine Mountain Range is notably steep and rocky with some peaks over 1500

$84 \mathrm{~m}$ a.s.1. Surficial deposits are generally less than a few metres thick and bedrock exposures are

85 more numerous, except in valley bottoms where thicker deposits occur.

\section{$86 \quad$ Methods}

87 Terrain mapping of six 1:50 000-scale NTS map areas (093J05, 06, 11, 12, 13, and 14; Maynard et al. 2013a, b, $c$; Sacco et al. 2013b, $c$; Ward et al. 2013) used standardized terrain mapping 89 methods based on sediment-landform associations (Resources Inventory Committee 1996;

90 Howes and Kenk 1997) supplemented with detailed ground observations. Polygons were

91 delineated and interpreted based on surficial material, surface expression and geomorphological 92 processes using 1:40 000-scale, black-and-white aerial photographs acquired in 1996 and 1997.

93 Point and line symbols were used to indicate features that could not be represented in the 94 polygon labels (e.g. streamlined features, eskers, meltwater channels). Field verification was 95 conducted by truck, ATV and foot traverses. Stratigraphic sections were described and units 96 were characterized using colour, texture, sorting, stratification, sedimentary structures and 97 contact relationships. Dominant ice-flow directions were determined using streamlined macroforms that are interpreted to represent the dominant ice-flow direction (Figure 2b). These features, including drumlins, 100 flutings, crag and tails, and streamlined bedrock, were identified on aerial photographs and a 101 digital elevation model (DEM) from Canadian Digital Elevation Data (GeoBaseC 2009), and 102 supplemented with microform (i.e. striations, rat tails and grooves) and till clast fabric data measured in the field. Relative ice-flow chronologies were determined from microforms based 
104

105

106

107

108

109

110

111

112

113

114

115

116

117

118

119

120

121

122

123

124

125

126

on truncated rat tails, striations that are formed within grooves, and striations on lee surfaces that would have been protected from later ice-flow. The trends of vertical series of clast a-axis till fabrics were also used to infer potential variations in ice-flow direction throughout the deposition of the till unit. These inferences were used with caution when determining the glacial history if the trends were not corroborated by other evidence as the clast orientations can be influenced by other processes.

Meltwater channels, ice-contact deposits, and glaciolacustrine sediments and landforms identified in the terrain mapping were used to determine the morphology of the glacier margin and drainage systems during deglaciation (cf. Fulton 1967; Plouffe 2000; Figure 2b-f). Similar landforms and sediments outside the terrain mapping extent were identified using aerial photography, the DEM, and where possible, verified with ground observations. Lateral meltwater channels were used to determine the shape and successive positions of the ice margin. The minimum extents of glacial lakes were inferred from the maximum elevations of aerially extensive glaciolacustrine deposits and delta topset beds and the minimum elevations of spillways measured from the DEM. The potential sizes and positions of glacial lakes as they evolved during deglaciation are reconstructed by digitally 'flooding' the DEM surface to match significant landforms.

Minimum ages for deglaciation were determined using optical dating of aeolian sediments that directly overlie glacial sediments (see lithostratigraphy section for description of aeolian sediments). Optical dating measures the time elapsed since grains of quartz or feldspar were last exposed to adequate sunlight or heat, which for aeolian sediment, corresponds to the time since those grains were buried. The possibility of inadequate sunlight exposure prior to burial is the most significant factor that can lead to an inaccurate optical age. Thus, aeolian sediment is a 
127 good candidate for optical dating because it is typically exposed to sufficient sunlight before

128 burial. Samples were collected by inserting an opaque $15 \times 8 \mathrm{~cm}$ ABS tube into a freshly exposed

129 vertical section. Samples were collected near the base of the deposits in an effort to obtain

130 material that was deposited soon after ice retreat. Zones with evidence of bioturbation or other

131 post-depositional disturbances were avoided as these processes can introduce grains with

132 different light exposure histories. All sample tubes were completely filled with material to keep

133 the contents immobile and the slip caps were reinforced with duct tape to provide an air-tight

134 seal to retain the as-collected water contents. Details of the method are discussed in Lian and

135 Roberts (2006) and Lian (2013), and experimental details are reported in Appendix A.

\section{Surficial geology}

137 Most sediments and landforms in the study area are products of the Fraser Glaciation. Figure 2 is

138 a simplified surficial map that represents six 1:50 000 terrain maps (Maynard et al. 2013a, b, $c$;

139 Sacco et al. 2013b, $c$; Ward et al. 2013).

140 Till is the dominant surficial material in the study area (Figure 2) and is generally a highly

141 compacted matrix-supported diamicton with clast contents ranging from $10-30 \%$. The thickest

142 till occurs in low-relief areas where it masks the underlying topography, and is commonly

143 streamlined. In uplands, it mantles the underlying topography as blankets and veneers. Bedrock

144 is exposed on the steepest slopes commonly with colluvial veneers and blankets composed of a

145 mixture of remobilized till and angular bedrock fragments. Colluvial fans composed of stratified

146 sand, gravel and diamictons occur at the mouths of steep drainages. Bedrock is only exposed in

147 isolated outcrops in the rest of the study area. 
148 Glaciofluvial sand and gravel deposits occur in a complex of subglacial, ice-marginal and 149 proglacial meltwater channels. Subglacial channels are generally oriented to the northeast, 150 aligned parallel to the deglacial ice-flow direction. Lateral channels are more common, occurring 151 as a series of sub-parallel northwest-southeast oriented features over most of the area. Proglacial 152 channels vary in direction as they were controlled by local topography. West of Carp Lake, thick 153 units of sand and gravel were deposited in a series of proglacial and lateral channels that formed 154 large outwash plains. These and other large plains along the McLeod, MacDougall and Salmon 155 rivers were later incised forming terraces. Glaciofluvial sediment was also deposited in eskers 156 and other hummocky ice-contact features. Small eskers on the flanks of valleys or depressions 157 commonly lead to hummocky glaciofluvial and ablation till deposits, and indicate local ice 158 stagnation. Larger esker systems are commonly associated with subglacial drainage networks.

159 Thick blankets of glaciolacustrine sediments occur in large river valleys and low-lying areas to 160 the south. These deposits are generally composed of laminated beds of fine sand, silt and clay. 161 Holocene gully erosion has created steep slopes in some of these deposits, making them 162 susceptible to mass wasting. Glaciolacustrine sediments in the northern part of the study area are 163 rare, generally occurring in valleys as thin, coarse-grained sand, gravel, or diamict veneers, 164 typical of more ice-proximal deposition. Glacial lake outlets with minimum elevations of $1020 \mathrm{~m}$ 165 and $1100 \mathrm{~m}$, and deltaic deposits with a topset elevations of $690 \mathrm{~m}$ and $750 \mathrm{~m}$ were identified 166 associated with some of these deposits (Figure 2). Glacial lake outlets that occur beyond the 167 extent of mapping, but impounded glacial lakes within the study area, are identified on the 168 appropriate figure in the discussion section. Aeolian veneers and dunes occur overlying and 169 adjacent to glaciofluvial and glaciolacustrine deposits. These landforms are composed of fine 
170 sand and silt, and are typically massive or show minor cross-bedding. Although thin, these

171 aeolian deposits are common throughout the study area, and can be aerially extensive.

172 Modern fluvial deposits composed of sand and gravel are typically restricted to floodplains

173 within meltwater channels as most modern drainage follows systems created during deglaciation.

174 Organic deposits are common around slow moving streams, abandoned meltwater channels and

175 small lakes, and occur in depressions on a many poorly drained substrates such as till, fine-

176 grained glaciolacustrine material, or bedrock.

\section{Lithostratigraphy}

178 Numerous stratigraphic sections with varied exposure were described in the study area. Six 179 sections that are representative of the Quaternary stratigraphy of the study area are described 180 (Figures 2, 3). Sections DS-01, DS-02 and DS-03 are natural bluffs on the McDougall River. 181 Section DS-01 reveals the internal strata of a roughly $15 \mathrm{~m}$ high, northwest oriented drumlinoid 182 feature, and an additional $\sim 50$ m of sediment below the drumlinoid. Sections DS-02 and DS-03 183 expose the stratigraphy of glaciofluvial terraces in the river valley. Section DS-04 occurs within 184 a meltwater channel, and DS-05 on the east shore of McLeod Lake. Section DS-06 occurs 185 adjacent to several southeast trending meltwater channels and was created during the excavation 186 of a gravel pit.

187 Nine lithostratigraphic units are designated to facilitate description and interpretation of the 188 Quaternary succession (Table 1). The oldest units are described first. The relative chronology for 189 the stratigraphic units is determined by relative stratigraphic position.

190 Unit 1 was observed at section DS-01 and DS-04, which occur in the same north-draining 191 watershed. This unit is divided into three sub-units. Unit 1a (DS-04) consists of $>1.5 \mathrm{~m}$ of 
192 massive, moderately well sorted, medium and coarse sand. The lower contact of this unit is

193 covered. Unit $1 \mathrm{~b}$ (DS-04) is a 5.5-m coarsening-upward sequence of laminated and finely bedded

194 clay, silt and sand with localized faulting and at least one clastic dyke. The lowest portion of unit

$1951 \mathrm{~b}$ is composed of laminated clay and minor silt that grade into dominantly silt laminations near

196 the middle, and finely bedded silt and fine sand at the top. Localized faulting is concentrated in

197 the upper metre and around the clastic dyke. The exposed portion of the dyke is $10-15 \mathrm{~cm}$ thick

198 and composed mainly of laminated clay that generally parallels the dyke walls. It penetrates

199 obliquely to a depth of about $1 \mathrm{~m}$ over a length of about $3 \mathrm{~m}$. Unit 1c (DS-01) comprises about

$20011 \mathrm{~m}$ of interstratified sand, gravel and diamict beds with an apparent dip of $10^{\circ}$ to the east. The

201 lowermost $2 \mathrm{~m}$ is a dark grey, silty, matrix-supported diamict containing massive to weakly

202 stratified muddy sand lenses. It has 15\% subrounded to rounded clasts, and the upper portion

203 passes into $20 \mathrm{~cm}$ of normally graded fine sand and silt. The lower diamict is conformably

204 overlain by $5-30 \mathrm{~cm}$ undulating and discontinuous beds of fine to coarse sand, well rounded

205 pebble gravel and minor lenses of diamict (Figure 4b). Fine sand beds in the upper part of this

206 exposure contain soft-sediment deformation and dewatering structures (Figure 4c). The lower

207 contact is covered.

208 Unit 1 is interpreted as advance-phase glacial lake sediments. In unit 1a, the sediment size,

209 sorting and lack of structure suggest that this unit was deposited rapidly in a shallow lake,

210 although a fluvial genesis is possible. In unit $1 \mathrm{~b}$, the fine-grained, laminated sediments are

211 consistent with sedimentation in deep water. The coarsening upwards indicates increasing energy

212 levels, likely due to higher flow regimes as a result of advancing ice. Localized faulting in the

213 upper section is interpreted as glacial tectonization. The brittle deformation around the clastic

214 dyke and laminations parallel to the dyke walls suggests it was injected into the substrate (cf. van 
215 der Meer et al. 2009), possibly when ice was overriding the site. The sequence of sediments and

216 dewatering structures in unit 1c are consistent with a prograding subaqueous fan (Reading 2009).

217 The gently dipping, discontinuous sand and gravel beds were likely deposited as the fan

218 aggraded into a glacial lake. Diamict lenses are likely sediment gravity flows down the fan 219 surface.

220 Unit 2 is observed at DS-01 where it comprises $15-17 \mathrm{~m}$ of compact, grey, sandy silty, matrix221 supported diamict with good fissility and jointing. Unit 2 may also occur in the north central part 222 of the study area where southeastward and northeastward trends were measured in till clast a-axis 223 fabric 09-01 (see ice-flow history section; Figure 7). It has $10-20 \%$ clasts of mixed lithologies.

224 These clasts are commonly striated and faceted. In the lower $40 \mathrm{~cm}$ of unit 2 , the matrix is 225 coarser which is interpreted as a gradational contact with the underlying unit 1c.

226 Unit 2 is interpreted as basal till based on compaction, sorting, clast morphology, and the 227 occurrence of fissility and jointing caused by glacitectonic shear (Benn and Evans 2010). Its 228 stratigraphic location below another glaciogenic diamict interpreted as basal till (unit 4) and 229 interbedded sand, silt and diamict (unit 3) indicate this till was likely deposited during an early 230 glacial advance. The beds dipping to the east in the underlying subaqueous outwash (unit 1c) 231 suggest that the advance came from a source area to the west. The exact age of units $1 \mathrm{c}$ and 2 are 232 unknown, but the lack of oxidation suggests these were deposited during the Fraser Glaciation.

233 Unit 3 only occurs at section DS-01. Its lower contact with unit 2 is irregular, consisting of 234 chaotically interbedded diamict and sand. It is $20-25 \mathrm{~m}$ thick and dominated by $\sim 1-\mathrm{m}$ thick 235 diamict layers and interbeds of coarse sand and moderately to well rounded pebble gravel 
236 between $0.5-1 \mathrm{~m}$ thick. Laminated and thin-bedded silt and fine sand beds occur near the top of 237 the unit.

238 The interbedded sand and diamict layers of Unit 3 are consistent with a subaqueous outwash fan, 239 and the fine-grained laminations indicate the sediment was likely deposited in a glacial lake. The 240 high frequency of diamict beds, which are interpreted as subaqueous debris flows from the 241 glacier, suggests they may have been deposited in close proximity to ice. Thinly-bedded silt and 242 sand deposited near the top of this unit indicate a lower energy environment, implying retreat of 243 the ice margin. Unit 3 contains sediments related to ice-proximal and distal conditions and 244 occurs between two diamicts interpreted as basal till, thus it was likely deposited during an 245 oscillation of the ice margin. An alternate hypothesis is that this unit was deposited subglacially.

246 Unit 4 occurs in sections DS-01/02/03/04/05 and in most surface and shallow exposures 247 throughout the study area. It is a massive compact diamict and supported by a matrix of sandy 248 silt, and typically shows good fissility and moderate jointing. Most of this unit is dark grey, 249 except where it has weathered to light brown. Exposed thicknesses range from 5 to $25 \mathrm{~m}$. In the 250 stratigraphic exposures, subangular to subrounded clasts of mixed-lithologies comprise $10-20 \%$ 251 of the material, although clast contents of up to $30 \%$ were observed. Clast a-axis fabrics were 252 measured from this unit in various exposures throughout the study area and generally show a 253 strong unimodal distribution parallel or sub-parallel to the local orientation of streamlines 254 macroforms. Clast of unit 4 in sections DS-02 and DS-03 become slightly more rounded and 255 diverse in lithology higher in the exposures. Sorted lenses of sand were observed in unit 4 at 256 section DS-03. The lower contacts of unit 4 are commonly erosive (DS-02 and DS-04), but also 257 occur as gradational (DS-03) or interbedded (DS-01). Unit 4 is interpreted as basal till based on 258 compaction, sorting, clast morphology, the occurrence of fissility and jointing, the strong 
259 unimodal clast a-axis fabric, and regional extent. This unit occurs at surface throughout most of 260 the study area, and therefore, is interpreted as Fraser glaciation till.

261 Unit 5 was observed remotely from the opposite side of the river overlying unit 4 at section DS-

26201 ; only a limited description is possible. It is a crudely stratified diamict ranging in thickness

263 from 3 to $6 \mathrm{~m}$. It is dominantly matrix-supported with some clast-supported areas. The clast

264 content appears to range from about 20 to $60 \%$. The lower contact is defined by a thin,

265 apparently continuous, large cobbly-gravel lag that is roughly parallel to the surface. This unit is 266 interpreted as ablation till based on the sorting, crude stratification and stratigraphic location over 267 basal till (unit 4). The clast lag observed between the units may represent basal sediment that was 268 washed by subglacial meltwater prior to the deposition of en- and supra-glacially transported 269 material.

270 Unit 6 is divided into two sub-units and was observed at section DS-03 (unit 6a and b) and DS27105 (unit $6 \mathrm{~b}$ ). Unit $6 \mathrm{a}$ is about $6 \mathrm{~m}$ thick and fines upwards from well rounded pebble gravel into 272 stratified, cross-bedded medium sand that is sharply overlain by another layer of pebble gravel.

273 The lower contact is gradational with unit 4 over $5 \mathrm{~cm}$. Throughout the unit are discontinuous, 25

$274-75-\mathrm{cm}$-thick, silty sandy matrix-supported diamict beds with sharp upper and lower contacts.

275 Unit $6 \mathrm{~b}$ consists of laminated and finely bedded silt and sand. At section DS-05, this unit consists

276 of $2.1 \mathrm{~m}$ of laminated silt and fine sand with $1-3 \mathrm{~cm}$ thick clay laminations at $10-20 \mathrm{~cm}$

277 intervals. At section DS-03, unit $6 \mathrm{~b}$ consists of $1 \mathrm{~m}$ of laminated and finely bedded silt and fine 278 sand with dropstones. The lower contact of unit $6 \mathrm{~b}$ is conformable with unit $6 \mathrm{a}$ at section DS-03

279 and with unit 4 at section DS-05. Unit 6a is interpreted as an ice-proximal subaqueous fan 280 deposit because of the interbedded sand and gravel, the discontinuous lenses of diamict that are 281 consistent with subaqueous debris flows, and its stratigraphic location beneath more distal glacial 
282 lacustrine sediments (i.e. Unit 6b). The alternation between sand and gravel suggests different

283 flow regimes, likely due to different meltwater discharges. The fine-grained laminations of Unit

$2846 \mathrm{~b}$ indicate farther proximity from the ice where distal underflow and suspension settling occurs

285 in glacial lakes (Shaw and Archer 1979). Unit 6 is interpreted as deglacial glaciolacustrine

286 sediment because it stratigraphically overlies basal till.

287 Unit 7 is observed at sections DS-02/03/05/06 and in numerous shallow exposures throughout

288 the area. It is composed of moderately sorted to well sorted, rounded to well-rounded, pebble- to

289 cobble-sized gravel that generally fines upwards. Deposits are typically clast-supported with a

290 coarse sand matrix. All observed lower contacts are erosive. In stratigraphic exposures, these

291 deposits range from $<1$ to $5 \mathrm{~m}$ thick, but may be thicker in large outwash corridors. At section

292 DS-06, unit 7 is composed of moderately rounded to well rounded, moderately sorted gravel that

293 coarsens and becomes less sorted upwards. At section DS-02, discontinuous beds of unit 7 occur

294 perched on narrow terraces in the diamict at 20,29 and $35 \mathrm{~m}$ above present-day river level. Unit

2957 is interpreted as glaciofluvial sediment and, based on its stratigraphic position over till, is

296 interpreted to have been deposited during ice retreat.

297 Unit 8 was only observed at section DS-06. It is as a compact, dark grey, silty sand, matrix-

298 supported diamict with less defined jointing and fissility than units 2 and 4 . It has a 20\% clast

299 content, which is of mixed lithology, with stones that are moderately rounded; some are striated

300 and faceted. The lower contact is gradational over $10 \mathrm{~cm}$ with the underlying gravel of unit 7.

301 This unit is interpreted as basal till based on compaction, sorting, clast morphology, and the

302 occurrence of fissility and jointing. It is slightly less consolidated and thinner than till unit 4.

303 Unit 8 is underlain by unit 7 (retreat glaciofluvial) and unit 4 (basal till) indicating it was 
304 deposited during a re-advance. The re-advance was likely a temporary oscillation of the ice 305 margin during the retreat phase.

306 Unit 9 does not occur at any of the described stratigraphic sections, and therefore, is not depicted 307 in the stratigraphic logs. It consists of well-sorted silt to fine sand with cross-bedding apparent in 308 some exposures, and was observed overlying or adjacent to glaciofluvial and glaciolacustrine 309 deposits. Unit 9 is interpreted as aeolian material that was sourced from unvegetated 310 glaciofluvial and glaciolacustrine deposits. Most aeolian landforms are discontinuous mantles or 311 poorly-formed dunes generally less than two metres thick with some dunes reaching several 312 metres in height. The thin-nature of the deposits, generally poorly developed dune structures, and 313 lack of identified buried soil horizons suggest that aeolian activity was short-lived with no 314 indication of reactivation (Sacco 2012).

\section{Chronology}

316 The chronology of deglaciation in the study area is only understood in a broad context. Regional 317 radiocarbon ages suggest that the study area was ice free before $\sim 10200{ }^{14} \mathrm{C}$ yr $(\sim 12000 \mathrm{cal} \mathrm{yr})$ 318 BP (Table 2). Refinement of this hypothesis using additional radiocarbon dating is restricted by 319 the lack of datable organic material from the earliest part of the post-glacial period. For example, 320 a piece of wood collected from the base of a peat deposit in an esker system yielded an age of 8 $321775 \pm 30{ }^{14} \mathrm{C}$ yr BP (UCAIMS 83989; Table 2; Figure 1). This age provides a minimum age for 322 ice retreat beyond the esker system, but more accurately records the timing of initial post-glacial 323 peat development, which significantly post-dates deglaciation. Therefore, we use optical dating 324 to determine when post-glacial aeolian material was deposited as a proxy for ice retreat. The use 325 and accuracy of this proxy is based on the assumption that the most recent aeolian activity 
326 occurred soon after ice retreat. The true age for deglaciation is the optical age plus the duration

327 of aeolian activity before final burial of the sampled sediment.

328 Four aeolian sediment samples were processed and analysed (samples MLD1, CLR5, OCDF4

329 and OCDF5; Figure 2). Samples MLD1, CLR5, and OCDF5 were collected from aeolian mantles

330 about $50 \mathrm{~cm}$ above the underlying glaciofluvial material. Sample OCDF4 was collected near the

331 base of a well-formed dune with a crest-height of about $2 \mathrm{~m}$. The underlying contact could not be

332 exposed.

333 Sample OCDF5 yielded optical ages of $8.79 \pm 0.51 \mathrm{ka}$ for quartz and $9.94 \pm 0.77 \mathrm{ka}$ for fine-

334 grained K-feldspar (Table 3); the quartz age is considered minimum age for this sample as it

335 failed a dose-recovery test (see Appendix A). Sample CLR5 yielded a fine-grained K-feldspar

336 age of $9.35 \pm 0.64 \mathrm{ka}$, and sample OCDF4 yielded a fine-grained K-feldspar age of $13.3 \pm 1.0 \mathrm{ka}$.

337 Sample MLD1 was abandoned; see discussion in Appendix A. All K-feldspar ages were

338 corrected for anomalous fading using the method of Huntley and Lamothe (2001). Figure 5

339 summarizes the experimental methods.

340 Ice-flow history

341 Streamlined macroforms were identified during mapping and are interpreted to represent ice flow

342 at Fraser Glaciation maximum and possibly during early deglaciation (Figure 6). These

343 landforms indicate that northeastward ice-flow was dominant with minor variation to the north

344 and the east (Figure 6). The northward deviations are probably the result of local topographic

345 control on a thinning ice sheet. East-west oriented landforms are only observed in the western

346 part of the study area. 
347 Microforms (striations, grooves and rat tails) were measured at 41 sites. Specific flow directions

348 were determined at nine locations (Figure 6). From these data, three broad trends and relative

349 ages are identified. Striations of the oldest group were measured at eight locations in the northern

350 part of the study area with orientations from $320^{\circ}-140^{\circ}$ to $280^{\circ}-100^{\circ}$ (Figure 6; green

351 symbols). They are nearly perpendicular to the streamlined features in some areas and are

352 interpreted to record early ice flow from a source area in the Omineca Mountains. The second

353 oldest group of striations has orientations from $190^{\circ}-10^{\circ}$ to $260^{\circ}-80^{\circ}$ (Figure 6 ; black

354 symbols). Although the range of orientations in this group is high, they are in agreement with the

355 trend of the local streamlined features; thus they likely developed contemporaneously during

356 glacial maximum and the early stages of deglaciation. Striations of the youngest group were

357 measured at eight locations only in the western portion of the study area and range from an

358 orientation of $250^{\circ}-70^{\circ}$ to a direction of $95^{\circ}$ (Figure 6 ; red symbols). They are interpreted to

359 relate to ice flow during later stages of deglaciation. At one key site, three ages of ice flow were

360 determined: the oldest flow direction is $60^{\circ}$, the second trends at $80^{\circ}-260^{\circ}$ and the final is $95^{\circ}$.

361 The oldest striation set in the series is aligned with local streamlined macroforms. The younger

362 two striation sets represent the transition to eastward ice-flow during deglaciation.

363 Till clast a-axis fabrics were measured at 13 locations in the study area (Figure 7; Table 4). At

364 four locations ( sites 6 -9), two fabrics were measured at different depths in vertically aligned

365 positions to identify potential changes in ice-flow direction. Most fabrics are thought to be within

366 Unit 4 and are in general agreement with the orientations of the local streamlined macroforms,

367 with a few exceptions. Fabric 09-01, with a major trend at $350^{\circ}-170^{\circ}$ and a weaker one at $225^{\circ}$

$368-45^{\circ}$, is interpreted to have developed primarily during the southeastward ice-advance and was 
369 partly realigned during the north-northeastward flow indicated by the orientation of streamlined 370 landforms.

371 The ice-flow direction inferred from fabric $09-03$ is about $350^{\circ}$. However, the macroforms in the 372 area are oriented in a more northeastward direction, at about $35^{\circ}$. Similarly, fabric 09-05 has a

373 minor northward trending component. The primary trend in fabric $09-05$ is about $85^{\circ}-265^{\circ}$ and 374 reflects ice flow during the late-glacial phase. The origin of these northward components has not 375 been resolved.

376 The principal eigenvector of fabric 09-06 indicates ice flow to the northeast, which is consistent 377 with the macroforms. The clast measurements, however, are spread along the outer edge of the 378 southwest and northeast quadrants suggesting that more than one ice-flow direction may have 379 affected the fabric; possibly during the transition to more eastward flow during the deglacial 380 phase. Otherwise, the dispersion may simply be due to till-forming processes (e.g. local changes 381 in the strain direction, clast collisions).

382 Two of the vertical fabric series show differences in dominant trend. In the west-central part of 383 the study area, the lower till fabric (10-01) trends to the northeast $\left(45^{\circ}\right)$, parallel to the fluting 384 from which it was collected. The upper fabric (10-02) trends more eastward (at $\left.85^{\circ}\right)$. This is 385 interpreted to reflect a shift in ice-flow direction to the east during deglaciation, which is 386 corroborated by sequenced striations to the north and south (Figure 6). In the northeast part of 387 the study area, the lower till fabric (11-02) is in agreement with the macroforms, trending about $38815^{\circ}$. The upper fabric (11-01) trends more to the northeast at about $50^{\circ}$, similar to that of a local 389 striation measurement (Figure 6). The eastward deviations of the fabric trend and striations from 
390 the macroforms are interpreted to reflect an eastward shift in ice-flow during deglaciation due to 391 topographic influence (see discussion).

392 Three stages of ice-flow were determined from the orientations of macroforms, microforms and 393 clast fabrics. During the first stage, ice flowed southeast into at least the northern part of the 394 study area; it is unknown how much of the area was affected by this event. The second stage was 395 to the northeast, which was the direction ice was flowing during the glacial maximum. During 396 deglaciation, ice-flow direction transitioned back to the east. The absence of late-phase, eastward 397 oriented indicators in the northeast suggest that the area was deglaciated when the southern and 398 western sector were under the influence of eastward flowing ice.

399 Discussion

400 Local glacial history

401 At the onset of the last glaciation, ice advanced toward the study area from source areas in the 402 Skeena, Omineca, Coast and Cariboo mountains. Initially, southeast flowing ice from the 403 Omineca Mountains impeded drainage to the north through the ancestral Parsnip River north of 404 McLeod Lake, forming a glacial lake of unknown extent in the northeast corner of the study area. 405 This ice was likely the first to reach the study area. Unit 1a (moderately well sorted sand, section 406 DS-04) was likely deposited in the early phases of the glacial lake. As the lake level increased, 407 unit $1 \mathrm{~b}$ (glaciolacustrine clay, silt and sand, section DS-04) was deposited. When ice was near 408 section DS-01, a subaqueous outwash fan (unit 1c) formed. Ice then advanced, most likely 409 toward the southeast as evidenced by the orientation of the early striations (Figure 6, green 410 symbols) and the southward oriented till fabric (Figure 7, fabric 09-01), depositing unit 2. The 411 extent of this early advance is unknown, but no evidence of southward flow was observed south 
412 of $\sim 54.7^{\circ} \mathrm{N}$, thus the southern portion of the study area may not have been covered by ice at this

413 time. Ice then retreated back to at least the location of section DS-01 when more subaqueous

414 outwash (unit 4) was deposited over the early advance till.

415 As glaciation intensified, ice from the Coast, Omineca and Cariboo mountains coalesced

416 producing a north eastward flow that continued throughout glacial maximum. The streamlined

417 macroforms, striations (Figure 6, black symbols) and many of the till fabrics throughout the area

418 record this northeast ice-flow.

419 As the climate ameliorated near the end of the Late Wisconsinan, the CIS began to retreat.

420 Initially, the ice front thinned along the western flanks of the Rocky Mountains and then

421 retreated to the southwest, toward the study area. Northward oriented macroforms in the

422 northeast part of the study area (Figure 6) indicate that the northward oriented Rocky Mountain

423 Trench caused local variations in ice flow to the north. Stacked till fabrics measured south of the

424 trench (fabrics 11-02 and 11-01; Figure 7) indicate a transition in ice-flow direction from north,

425 back to northeast, likely when the ice retreated enough that flow was not affected by the Rocky

426 Mountain Trench. At this time, subglacial meltwater flowed north to the northeast through

427 several systems into the Peace River Basin (Figure 8a). The longest meltwater system can be

428 traced from Salmon to McDougall valleys. It transitions between eskers and subglacial channels

429 as it crosses the drainage divide of Mount Mackinnon and continues over the uplands and

430 beyond the study area. Two meltwater systems developed off the arms of Carp Lake and

431 extended northeast into the northern McLeod Lake valley. Shallow meltwater channels and a

432 series of eskers indicate that, at some point, meltwater from the east arm system was diverted

433 north into McLeod River valley (Figure 8a). 
434 Ice retreated from the northeast part of the study area along a mostly straight, northwest435 southeast-trending margin as indicated by the orientation of lateral meltwater channels (Figure 436 8b). Meltwater continued to be discharged into the McLeod Lake valley, but was blocked just 437 north of the study area, forming a large glacial lake, informally named glacial Lake McLeod. Silt 438 and sand (unit $6 \mathrm{~b}$, section DS-05) were deposited in this lake about $20 \mathrm{~m}$ above the level of 439 present-day McLeod Lake. Meltwater moving through the McDougall River valley was diverted 440 southeast along the retreating ice margin, cutting a series of channels leading to the McLeod 441 River; the youngest channel is the present course of the McDougall River. Meltwater, partly 442 supplied by subglacial drainage flowing over the north end of Mount Mackinnon, continued to 443 be directed into the uplands and through the McDougall River until the ice retreated to lower 444 elevations (Figure 8b). Ice continued to retreat and a sediment or ice dam caused local ponding 445 of a glacial lake in McDougall River valley. Cross-bedded sands were deposited by underflow 446 currents, while failures from the unstable valley walls or ice front deposited discontinuous 447 diamict beds (unit 6a; section DS-03). It is unlikely that both glacial lakes were connected due to 448 the $\sim 100 \mathrm{~m}$ difference in elevation between glaciolacustrine units in the McDougall River and 449 McLeod Lake valleys. A $100 \mathrm{~m}$ deep lake extending from McLeod lake to the location of this 450 section would submerge a significant area, from which no glaciolacustrine sediments or 451 landforms were mapped. Eventually the blockage was removed and cobble gravel was deposited 452 on the valley floor (unit 7; sections DS-02 and DS-03).

453 The ice mass that impeded northward drainage forming glacial lake McLeod is roughly 454 delineated by hummocky gravels, a large esker complex and a large kettle lake (presently 455 Tudyah Lake) (Figure 9a). The southern limit of the lake was the retreating ice margin and the 456 lake expanded as this margin retreated up the valley. The highest water level was at least $750 \mathrm{~m}$ 
457 a.s.1. as indicated by deltaic sediments, a spillway draining east into the Parsnip River valley, and 458 a south-dipping ice-marginal channel cut into the east valley wall that connected glacial lakes 459 McLeod and Fraser (Figure 9a). At this water level, the lake occupied about a $100 \mathrm{~km}$ length of 460 the valley between the blocking ice mass on the north and the ice margin on the south (Figure $4619 a)$.

462 Continued ice retreat exposed the southern part of the Crooked River valley and widened the 463 connection between glacial lakes McLeod and Fraser. The water elevation was likely controlled 464 by the ice mass in the north. A second lake elevation of $690 \mathrm{~m}$ a.s.1. is inferred from the elevation 465 of topsets on two deltas at the mouth of the McLeod River (Figure 9b). At this elevation, the lake 466 could be contained by an ice mass the size of Tudyah Lake. Many of the topographic highs in the 467 southern part of the valley were exposed. Glacial Lake Fraser was likely still draining north into 468 glacial Lake McLeod as its water spilled over the drainage divide and through the channel at an 469 elevation of $715 \mathrm{~m}$ a.s.1. in the south end of the valley.

470 As the ice continued to retreat, meltwater was diverted from the McDougall River and flowed 471 southeast along the ice margin to Carp Lake (Figure 8c). A chaotic system of meltwater channels 472 developed in which subglacial channels carried water northeast towards the ice margin. As the 473 ice margin retreated, new lateral channels flowing to the southeast progressively formed at lower 474 elevations, following the ice front position and cross-cutting the subglacial channels. Outwash 475 plains that end abruptly at the limits of Carp Lake suggest that they formed against stagnant ice 476 blocks that occupied the lake basin. A proglacial lake developed around Weadon Lake to a 477 minimum elevation of $780 \mathrm{~m}$ a.s.l. Northern drainage was impeded by an ice mass in the 478 Crooked River valley (Figure 8c, 9a). A series of eskers indicates some drainage below the ice 
479 mass, and a channel cut into the west wall of the Crooked River valley suggests that drainage 480 also occurred adjacent to the ice mass (Figure 9a).

481 When the northern ice margin began retreating down the uplands in the northwest part of the 482 study area, several ice-marginal lakes were impounded and perched glaciolacustrine sediments 483 were deposited (Figure 8c). Spillways indicate a minimum elevation of about $1020 \mathrm{~m}$ a.s.1. for 484 the northern lake and $1100 \mathrm{~m}$ a.s.l. for the southern lake. The lakes existed along the retreating 485 ice margin until the water was able to drain southeast, south of Mount Mackinnon.

486 When the ice margin was south of the drainage divide separating the Arctic and Pacific 487 watersheds, all proglacial meltwater began flowing southeast along the ice margin (Figure 8d). 488 The ice front configuration, as reconstructed from the position of the lateral meltwater channels, 489 was generally straight and retreating to the southwest. During the retreat, there was a reduction 490 of influence from ice in the south resulting in a transition to eastward ice flow and a curved ice 491 margin (Figure 8e). The transition to eastward ice-flow is illustrated in the southwest by 492 macroforms (Figure 6), till fabrics 10-01, 10-02, and 09-05 (Figure 7), and striations northwest 493 of Great Beaver Lake (Figure 6, black and red symbols). Striations on the west side of NTS 494 093J12 (Figure 6, red symbols) and till fabric 09-06 (Figure 7) also indicate eastward ice flow. 495 At least one oscillation of the ice front was associated with the changing ice dynamics. This is 496 recorded at section DS-06 where a thin layer of till (unit 8) overlies outwash gravel (unit 7).

497 A glacial lake formed around what is now Great Beaver Lake to a minimum elevation of $795 \mathrm{~m}$ 498 a.s.1. (Figure 8e). Ice-contact deposits suggest that the two possible outlets at $780 \mathrm{~m}$ a.s.1. were 499 blocked by ice. The lake drained through the lower Salmon River valley. 
500 Ice retreated south across the southern adjacent map area (Clague 1988) and west through the 501 western adjacent map area (Plouffe 2000), implying that the ice margin continued to diverge 502 beyond the study area. The western ice lobe retreated across the Interior Plateau, eventually 503 breaking up into ice tongues that occupied depressions such as the Babine, Francois and Takla 504 Lake valleys (Levson et al. 1998; Stumpf et al. 2000). Meltwater from these glaciers drained into 505 glacial Lake Fraser, which is thought to have occupied much of the Fraser Basin including parts 506 of the Nechako and Stuart river valleys (Tipper 1971a; Clague 1988, 1989; Plouffe 1997, 2000).

507 The exact configuration and morphology of glacial Lake Fraser is unknown. It has been 508 suggested that it existed as a series of lakes in multiple basins (Tipper 1971a), and conversely, as 509 a single lake reaching a surface elevation of $800 \mathrm{~m}$ a.s.l. (Clague 1987). The elevation of the 510 spillway into the Peace River basin limited the elevation of the northeastern extent of the lake to $511715 \mathrm{~m}$ a.s.1., although early phases of the lake may have reached an elevation of $750 \mathrm{~m}$ a.s.1.

512 when glaciers still covered the spillway. Elevations of mapped glaciolacustrine sediments 513 attributed to glacial Lake Fraser increase to the southwest, and to a greater extent to the west 514 (e.g. 760 - $780 \mathrm{~m}$ a.s.1. around Stuart lake (Plouffe 2000; this study); $760 \mathrm{~m}$ a.s.1. in the Prince 515 George area (Tipper 1971b); 800 m a.s.l. west of Prince George (Blais-Stevens and Clague 516 2007); and $875 \mathrm{~m}$ a.s.l. southwest of Vanderhoof (Sacco et al. 2014); Figure 10). However, there 517 is a decrease in elevation of the glacial lake sediments west of Vanderhoof (Plouffe 2000). The 518 inconsistency between these measurements suggest that glacial Lake Fraser was a time-

519 transgressive complex, likely influenced by the retreating ice margin and differential isostatic 520 depression.

521 The glacial lake that occupied the Stuart Lake basin was likely isolated from the early phases of 522 glacial Lake Fraser by a curved section of the retreating ice margin. The ice margin may have 
523 crossed the Stuart River valley where gullied glaciolacustrine sediments transition into a more

524 defined meltwater channel (figure 11). The large subglacial channel and inset esker complex

525 extending southeast could have formed during the draining of the lake. As the ice thinned,

526 hydrostatic pressure forced the lake to drain subglacially and cut the large channel. As flow

527 slowed, the large esker system was deposited within the channel. Wood collected at the base of a

528 peat deposit from an excavation pit between two esker ridges was submitted for radiocarbon

529 analysis in an attempt to date the timing of deglaciation. The sample yielded an age of $8775 \pm 30$

$530 \quad{ }^{14} \mathrm{C}$ yr BP (UCAIMS 83989; Table 2; Figure 1 and 11). It provides a minimum age for ice retreat

531 beyond the esker system, but most likely indicates the timing of initial post-glacial peat

532 development, which likely significantly post-dates deglaciation.

533 Reported radiocarbon ages from west of the study area suggest that ice retreated from the region

534 before $\sim 12000$ cal yr BP (Table 2). Based on radiocarbon chronology, we suspect that the

535 feldspar ages from samples OCDF5 (9.94 $\pm 0.77 \mathrm{ka})$ and CLR5 (9.35 $\pm 0.64 \mathrm{ka})$ are younger

536 than deglaciation. It is possible that aeolian activity continued for over 1000 years. However, this

537 explanation is not in agreement with the morphology of the landforms; if activity persisted for

538 that length of time, the dune landforms should be better developed and some migration from

539 their source areas would be expected (Sacco 2012). Alternatively, there may have been a brief

540 period of aeolian reactivation on a regional scale. Between 8000 and $10000 \mathrm{yr} \mathrm{BP}$, the climate in

541 the southern Interior was warmer and dryer than it is today (Hebda 1995). If this climate trend

542 extended north to the study area, some of the aeolian deposits could have reactivated, resulting in

543 the younger optical ages. Sample OCDF4 (13.3 $\pm 1.0 \mathrm{ka})$ yielded a fine-grained K-feldspar age

544 that is in better agreement with the reported regional radiocarbon ages, but is significantly older

545 than samples OCDF5 and CLR5. If this age is accurate, the younger ages (samples OCDF5 and 
546 CLR5) suggest there was a period(s) of reactivation that only affected some landforms.

547 Alternatively, sample OCD4 contains some grains that were not exposed to sufficient sunlight.

548 More chronologic data is needed to better resolve the timing of deglaciation in the region.

Regional ice-flow model for the northern Interior Plateau

550 The ice-flow model is described below in 3 phases: 1) ice-expansion; 2) glacial maximum; and

551 3) late glacial (Figure 12). The ice-expansion phase probably lasted late into the last glaciation

552 (Ryder and Maynard 1991; Bobrowsky and Rutter 1992; Stumpf et al. 2000). During this time,

553 ice accumulated and then expanded into the Northern Interior of British Columbia from the

554 north, west, southwest and southeast (Clague 1988, 1989; Plouffe 1997, 2000; Stumpf et al.

555 2000; Plouffe and Levson 2001a). The first glaciers that developed in the Omineca and Skeena

556 mountains flowed southeast down the northern Rocky Mountain Trench and the Takla and

557 Babine lake valleys (Ryder and Maynard 1991; Plouffe 1997; Stumpf et al. 2000; Levson 2001;

558 green arrows, Figure 12a). Multiple striation sites and a till fabric from this study suggest that the 559 glaciers also flowed southeast across the central part of the northern Interior Plateau and at least 560 into the northern uplands of the study area.

561 Ice from the Kitimat Ranges flowed eastward across the northern Interior Plateau (Plouffe 1997, 562 2000; Stumpf et al. 2000; Plouffe and Levson 2001a). These glaciers interacted with the glaciers 563 sourced in the Skeena and Omineca mountains producing an eastward transition in their flow 564 direction (yellow arrows, Figure 12a). Eventually, ice from the Cariboo Mountains and Pacific 565 Ranges reached the northern part of central British Columbia (Clague 1988, 1989; Plouffe 1997, 566 2000), which caused a deflection in flow to the northeast (blue arrows, Figure 12a). The exact 567 locations of the ice confluences are unknown. Based on the proximity of the Omineca and 
568 Skeena mountains to the north, the Kitimat Ranges and Hazelton Mountains to the west and the

569 Cariboo Mountains to the southeast, it is likely that ice masses from these source areas

570 coalesced, near the study area prior to the arrival of ice from the Pacific Ranges.

571 In the northern Interior of British Columbia the glacial maximum is thought to be marked by an

572 eastward shift of the ice divide from the Coast and Skeena mountains over Babine Lake Valley,

573 extending south to the Francois and Ootsa lake areas (Levson et al. 1998; Stumpf et al. 2000).

574 The east-west oriented macroforms in the adjacent map-area, NTS 093K (Plouffe 2000) reflect

575 the influence of this ice divide. In the study area, the dominance of northeastern ice-flow

576 indicators suggest that flow was controlled by the interaction between this ice divide and an ice

577 divide in the south through the maximum stage (Figure 12b).

578 During the late-glacial phase, the ice sheet thinned and retreated from the Rocky Mountains, and

579 ice flow at the margin became more influenced by the local topography. Initially, northern

580 deviations occurred as the ice surface lowered through the valleys north of the study area (orange

581 arrows, Figure 12c). As the ice retreated past the influence of these valleys, it began to flow more

582 to the east. The transition was likely affected by the reduced influence from ice flowing from the 583 south, due to downwasting and stagnation (Fulton, 1967, 1991; Plouffe et al. 2011). This allowed

584 an increased influence from the ice divide to the west, causing the final regional eastward ice-

585 flow (red arrows, Figure 12c).

586 Conceptual model for the deterioration of the CIS

587 Fulton's $(1967,1991)$ deglacial model for the Southern Interior describes active ice, transitional

588 upland, stagnant ice and dead ice phases. Although there are physiographic similarities between

589 northern and southern parts of the Interior, the absence of landforms associated with large-scale 
590 dead and stagnant ice indicate Fulton's model is not entirely applicable in the north (cf. Plouffe

591 2000). This is likely influenced by: 1) the ice divide in the Northern Interior that largely

592 remained east of the Coast Mountains during the early phases of deglaciation and connected with

593 valley glaciers when it shifted back to the mountains ( $c f$. Levson et al. 1998; Stumpf et al. 2000),

594 2) the proximity to local accumulation centres (Plouffe 2000), and 3) the limited occurrence of

595 deep topographic lows that served as loci for stagnation in the south.

596 Plouffe (2000) applied Fulton's (1967) model of deglaciation with minor modifications to map597 areas NTS 093N/K, west of the study area. He illustrates that ice tongues remained active and 598 connected to their sources throughout deglaciation. Levson et al. (1998) and Stumpf et al. (2000) 599 also conclude ice movement and connectivity late into deglaciation over the Nechako Plateau. In 600 this study area, the lack or regional ice stagnation deposits, relative deglacial ice flow 601 chronologies and the orientation of ice marginal meltwater channels illustrates localized 602 stagnation, and large-scale modifications to ice-flow and the shape of the ice margin as local 603 source areas became more influential during deglaciation. Here, Fulton's $(1967,1991)$ model of 604 deglaciation is refined with these findings to emphasize the reorganization of the ice sheet, 605 continued ice movement, and local rather than regional ice stagnation. The refined model is 606 specific to the northern Interior Plateau of British Columbia and consists of four phases: 1) 607 confluent ice sheet; 2) ice sheet reorganization; 3) valley; and 4) alpine.

608 The confluent ice sheet phase is analogous with Fulton's $(1967,1991)$ active ice phase. During 609 this phase the northwest-southeast-oriented ice front retreated to the southwest from the Rocky 610 Mountains into the northern Interior Plateau. The general ice-flow direction was similar to that of 611 the glacial maximum, but large topographic features caused local ice-flow variations at the 612 margin. Locally, ice masses detached from the ice front as it retreated across topographic 
613 irregularities. Examples of local ice stagnation are most common on the east side of topographic

614 highs, such as the ice dam that impounded glacial Lake McLeod and ice stagnation topography

615 on the northeast side of the uplands in NTS 093J13. During the ice sheet reorganization phase,

616 ice dynamics shifted to reflect major source areas. Specifically, the southern part of the margin

617 began to trend more east-west and northern part more north-south, and ice-flow near the northern

618 margin shifted east. Closer to the major source areas, ice was thinning and ice-flow became

619 increasingly influenced by topography (Stumpf et al. 2000). Ice-flow continued through this

620 phase and the ice front continued to retreat west through the Nechako Plateau (Plouffe 2000) and

621 south through the Fraser Basin (Clague 1988). The valley phase (analogous with Fulton's (1967,

622 1991) transitional upland phase) occurred when ice was limited to large valleys such as the

623 Babine and Ootsa lake valleys. Topographically controlled ice-flow continued in valley glaciers

624 that were still attached to source areas in the northern mountain ranges (Levson et al. 1998;

625 Plouffe 2000; Stumpf et al. 2000). Local ice stagnation presumably occurred during this phase as

626 ice blocks detached from retreating ice margins. During the final alpine phase, active ice was

627 limited to alpine regions. Climate fluctuations such as the Younger Dryas may have caused some

628 readvances/reactivation that later stagnated in alpine areas (e.g. Lakeman et al. 2008) within the

629 Coast Mountains.

630 Margold et al. (2013) present a model of the CIS retreat in central British Columbia

631 reconstructed from regional-scale investigations of meltwater landforms interpreted from

632 satellite imagery (Google Maps, SPOT) and digital elevation data (GeoBaseC 2009). Based on

633 ice surface profiles delineated through inversion modeling, they conclude that the pattern of

634 retreat was similar to that of the Fennoscandian ice sheet ( $c f$. Kleman et al. 1997), in which ice

635 retreated back into the source area along an irregular ice front with minimal stagnation. 
636 Specifically, the CIS retreated westward and southwestward back into the Coast Mountains. The

637 findings of the present study are in general agreement with this proposed style of frontal retreat

638 and the suggestion of major ice reorganization. However, the ice front locations during

639 deglaciation as depicted by Margold et al. (2013) are simplified because of the limited details

640 captured from the interpretation of small scale data. Our study, and others in the region (e.g.

641 Giles and Levson, 1995; Clague 1998a, b; Stumpf et al., 2000; Plouffe and Williams, 2001)

642 demonstrate that detailed mapping of landforms and ice-flow indicators at all scales provide a

643 more accurate view on ice from positions during deglaciation.

\section{Conclusions}

645 The purpose of this study is to establish a glacial history for the McLeod Lake map area based on 646 surficial geology mapping and ground observations. Our interpretation is placed in a regional 647 context that is founded upon similar research and together used to improve the understanding of 648 the events of the Fraser Glaciation in central British Columbia.

649 Previous studies indicate that the initial ice advance from the Omenica and Skeena mountains 650 flowed southeast down the major peripheral valleys. Data from this study suggest the ice also 651 occupied the northernmost parts of the Interior Plateau between the valleys, and that an ice-front 652 fluctuation occurred prior to the arrival of east flowing ice from the Coast Mountains. During 653 glacial maximum, ice masses from the north, west, southwest and southeast coalesced over the 654 Interior Plateau, and the ice divide shifted east from the Coast Mountains into the western part of 655 the northern Interior Plateau. Ice flow reversed on the west side of the divide, and continued in 656 an eastward direction, east of the divide. The eastward flow was diverted to the northeast by 657 glaciers sourced in the south. It is unknown when this diversion occurred in relation to the 
658 shifting ice divide. During initial deglaciation, decreased influence from the south resulted in a 659 transition of ice flow back to the east over much of the region.

660 Evidence of glacial lake formation during the advance and retreat phases of the Fraser Glaciation 661 is present in the lithostratigraphic record and surface landforms. At present, little is understood 662 about the configurations of advance-phase glacial lakes as evidence is sparse. The evolution of 663 glacial lakes during deglaciation, however, suggests the configuration of the lakes and drainage 664 networks was heavily influenced by the retreating ice margin. Glacial Lake Fraser occupied a 665 large area in the northern Interior Plateau during deglaciation. Differences in elevation of glacial 666 lake sediments and landforms across the region suggest glacial Lake Fraser existed as a time667 transgressive complex of smaller lakes. A better understanding of the glacial Lake Fraser 668 complex may be developed with increased temporal and spatial resolution of the ice margin 669 configuration using higher resolution surficial geology mapping and considering the effect of 670 isostasy.

671 A conceptual model of deglaciation specific to the northern Interior Plateau is proposed here. It 672 is refined from Fulton's $(1967,1991)$ conceptual model, and consists of four phases: 1) a 673 confluent ice sheet phase; 2) ice sheet reorganization phase; 3) valley glaciation phase; and 4) 674 alpine glaciation phase. The refinements consider the effects of interacting ice masses from 675 multiple source regions on the morphology and ice-flow of the CIS during deglaciation.

676 Deglacial chronological control is generally lacking over much of the interior of British 677 Columbia due to a lack of organic material for radiocarbon dating. Optical dating of post-glacial 678 aeolian sediments is an alternative means of constraining the time of deglaciation ( $c f$. Lian and 679 Huntley 1999; Hickin et al. 2016). Our optical dating experiments demonstrate that K-feldspar is 
680 a better geochronometer than quartz in this region. Fine silt K-feldspar post-glacial aeolian

681 landforms yielded optical ages of $13.3 \pm 1.0,9.94 \pm 0.77$ and $9.35 \pm 0.64 \mathrm{ka}$. There are two

682 possible interpretations of the optical ages: 1) deglaciation of the study area occurred around 13

$683 \mathrm{ka}$ and there were period(s) of reactivation in some localities, perhaps as a result of changes in

684 climate; or 2) at two sigma, the optical ages are in general agreement with the regional

685 radiocarbon ages associated with deglaciation, that range between 12.0 and 10.4 ka cal yrs BP

686 (Table 2), and can be used together as minimum ages for deglaciation. More optical dating of

687 stabilized aeolian landforms resting directly on glacial sediments would refine our knowledge of

688 the timing of deglaciation in the region.

689 Acknowledgments

690 Generous funding for this project was provided by Geoscience BC. We would like to thank all of

691 the field assistants, and the staff at the Luminescence Dating Laboratory at the University of the

692 Fraser Valley. Additional support was provided through Natural Sciences and Engineering

693 Research Council (NSERC) of Canada Discovery grants to B.C. Ward and O.B. Lian, and

694 through an NSERC Research Tools and Instruments Grant to O.B. Lian. We would also like to

695 thank Alain Plouffe and an anonymous reviewer for their thoughtful comments and suggestions

696 that improved the quality of the manuscript.

\section{References}

698 Alley, N. and Young, G. 1978. Environmental significance of geomorphic processes in northern

699 British Columbia west of the Rocky Mountains. BC Ministry of the Environment, Resource

700 Analysis Branch, Bulletin 3. 
701 Armstrong, J.E., and Tipper, H.W. 1948. Glaciation in north-central British Columbia. American 702 Journal of Science, 246: $283-310$.

703 Benn, D.I. and Evans, D.J.A. 2010. Glaciers \& glaciation $2^{\text {nd }}$ ed. Oxford University Press Inc., 704 New York, 816 p.

705

706

707

708

709

710

711

712

713

714

715

716

717

718

719

Bobrowsky, P.T., Sibbick, S.J., Newell, J.M., and Matysek, P.F., (eds.) 1995. Drift exploration in the Canadian Cordillera; British Columbia Ministry of Energy, Mines and Petroleum Resources, Victoria, British Columbia, Paper 1995-2, 304 p.

Blais-Stevens, A. and Clague, J.J. 2007. Surficial geology, southeastern portion of the Prince George map area, British Columbia. Geological Survey of Canada, Open File 5274, scale 1:100 000 .

Blake, W., Jr, 1986. Geological Survey of Canada radiocarbon dates; XXV. Geological Survey of Canada, Paper 85-7, 32p.

Boulton, G.S. 1987. A theory of drumlin formation by subglacial sediment deformation. In Menzies, J. and Rose, J. (eds), Drumlin Synopsium. Balkema, Rotterdam, pp. 25-80.

Bobrowsky, P. and Rutter, N.W. 1992. The Quaternary geologic history of the Canadian Rocky Mountains. Géographie physique et Quaternaire, 46: 5 - 50.

Bronk Ramsey, C. 2009. Bayesian analysis of radiocarbon dates. Radiocarbon, 5: 337-360.

Clague, J.J. 1988. Quaternary stratigraphy and history, Quesnel, British Columbia. Géographie physique et Quaternaire, 42: 279 - 288. 
720 Clague, J.J. (Compiler). 1989. Chapter 1. Quaternary geology of the Canadian Cordillera. In

721 Quaternary geology of Canada and Greenland Edited by R.J. Fulton and J.O. Wheeler.

722 Geological Survey of Canada, Geology of Canada, No. 1: 15 - 96.

723 Clague, J.J. 1998a. Surficial geology, Cluculz Lake, British Columbia; Geological Survey of

724 Canada, Open File 3638, scale 1:100 000.

725 Clague, J.J. 1998b. Surficial geology, West Road (Blackwater) River, British Columbia;

726 Geological Survey of Canada, Open File 3639, scale 1:100 000.

727 Clague, J.J., Hebda, R.J., and Mathewes, R.W. 1990. Stratigraphy and paleoecology of

728 Pleistocene interstadial sediments, central British Columbia. Quaternary Research, 34: 208 729226.

730 Clark, P.U. and Hansel, A.K. 1989. Clast ploughing, lodgement and glacier sliding over a soft 731 glacier bed. Boreas, 18: $201-207$.

732 Diakow, L.J. and Levson, V.M. 1997. Bedrock and surficial geology of the Southern Nechako 733 Plateau, Central British Columbia (NTS 93F/2, 3, 6, 7). BC Ministry of Employment and 734 Investment, British Columbia Geological Survey, Geoscience Map 1997-02, scale 1:100 000.

735 Diakow, L.J., Webster, I.C.L., Levson, V.M. and Giles, T.R. 1994. Bedrock and surficial 736 geology of the Fawnie Creek Map area (NTS 93F/3). BC Ministry of Energy, Mines and 737 Petroleum Resources, British Columbia Geological Survey, Open File 1994-02, scale 1:50 000.

738 Ferbey, T., Arnold, H. and Hickin, A.S. 2013. Ice-flow indicator compilation, British Columbia;

739 BC Ministry of Energy and Mines, BC Geological Survey, Open File 2013-06, scale

$740 \quad 1: 1650000, \mathrm{URL}$ 
$741<$ http://www.empr.gov.bc.ca/Mining/Geoscience/PublicationsCatalogue/OpenFiles/2013/Pages/

742 OF2013-06_iceflow.aspx> [October 2013].

743 Fulton, R.J. 1967. Deglaciation studies in Kamloops region, an area of moderate relief, British

744 Columbia. Geological Survey of Canada, Bulletin 165.

745 Fulton, R. J. 1991. A conceptual model for growth and decay of the Cordilleran Ice Sheet.

746 Géographie physique et Quaternaire, 45: 281-286.

747 GeoBase $^{\circledR}$.2009. Canadian digital elevation data, edition 3.0; Natural Resources Canada, URL

$748<$ http://www.geobase.ca/geobase/en/find.do?produit=cded $>$ [November 2012].

749 Giles, T.R. and Levson, V.M. 1995. Surficial geology and Quaternary stratigraphy of the Tsacha

750 Lake area (NTS 93F/2). BC Ministry of Energy, Mines and Petroleum Resources, British

751 Columbia Geological Survey, Open File 1995-10, scale 1:50 000.

752 Hartman, G.M.D., and Clague, J.J. 2008. Quaternary stratigraphy and glacial history of the Peace

753 River valley, northeast British Columbia. Canadian Journal of Earth Sciences, 45: 549 - 564.

754 Hebda, R. J. 1995. British Columbia vegetation and climate history with focus on 6 ka BP.

755 Geographie Physique et Quaternaire, 49: 55 - 79.

756 Hickin, A. S., Lian, O. B., Levson, V. M. and Cui, Y. 2015. Pattern and chronology of glacial

757 Lake Peace shorelines and implications for isostacy and ice-sheet configuration in northeastern

758 British Columbia, Canada. Boreas, 44: 288 - 304. 
759 Hickin, A.S., Lian O.B., and Levson, V.M. 2016. Coalescence of late Wisconsinan Cordilleran 760 and Laurentide ice sheets east of the Rocky Mountain Foothills in the Dawson Creek region, 761 northeast British Columbia, Canada, Quaternary Research, 85: 409 - 429.

762 Hicock, S.R., Goff, J.R., Lian, O.B., and Little, E.C. 1996. On the interpretation of subglacial till 763 fabric. Journal of Sedimentary Research, 66: 928 - 934.

764 Howes, D.E. and Kenk, E. 1997. Terrain classification system for British Columbia. Version 2. 765 British Columbia Ministry of Environment, Lands and Parks, Victoria, B.C.

766 Holland, S.S. 1976. Landforms of British Columbia: A physiographic outline. Department of 767 Mines and Petroleum Resources, Victoria, B.C.

768 Huntley, D.J. and Lamothe, M. 2001. Ubiquity of anomalous fading in K-feldspars and the 769 measurement and correction for it in optical dating. Canadian Journal of Earth Sciences, 38: $770 \quad 1093-1106$.

771 Kerr, D.E. 1991. Surficial geology of the Mount Milligan area (NTS 93N/1E; 93O/4W). BC 772 Ministry of Energy, Mines and Petroleum Resources, British Columbia Geological Survey, Open 773 File 1991-07, scale 1:50 000

774 Kleman, J.K., Hattestrand, C., Borgstrom, I., and Stroeven, A. 1997. Fennoscandian 775 palaeoglaciology reconstructed using a glacial geological inversion model. Journal of 776 Glaciology, 43: 283-299.

777 Lakeman, T. R., Clague, J. J., and Menounos, B. 2008. Advance of alpine glaciers during final 778 retreat of the Cordilleran Ice Sheet in the Finlay River area, northern British Columbia, Canada.

779 Quaternary Research, 69: 188 - 200. 
780 Leaming, S.P. and Armstrong, J.E. 1969. Surficial geology, Prince George, British Columbia.

781 Geological Survey of Canada, Map 3-1969, scale 1:250 000.

782 Lesemann, J.E., and Brennannd, T.A. 2009. Regional reconstruction of subglacial hydrology and 783 glaciodynamic behaviour along the southern margin of the Cordilleran Ice Sheet in British 784 Columbia, Canada and northern Washington State, USA. Quaternary Science Reviews, 28 (23785 24): $2420-2444$.

786 787 788 789 790 791 792 793 794 795 796 797 vol 2: pp. 653-666.

798 799 800 $1: 50000, \mathrm{URL}$
Levson, V.M. 2001. Quaternary geology of the Babine porphyry copper district; implications for geochemical exploration. Canadian Journal of Earth Sciences, 38: 733 - 749.

Levson, V.M. and Giles, T.R. 1994. Surficial geology and Quaternary stratigraphy of the Fawnie Creek area. BC Ministry of Energy and Mines, BC Geological Survey, Open File 1994-9, scale

<http://www.empr.gov.bc.ca/Mining/Geoscience/PublicationsCatalogue/OpenFiles/1994/Docum ents/OF1994-09.pdf> [September 2012].

Levson, V. M., Stumpf, A. J., Stuart, A. J., and Smyth, W. R. 1998. Quaternary geology and iceflow studies in the Smithers and Hazelton map-areas (93 L and M); implications for exploration. Ministry of Energy, Mines and Petroleum Resources Paper 1998-1: 5-16.

Lian, O.B. (2013). Optical Dating. In: Elias S.A. (ed). The Encyclopedia of Quaternary Science,

Levson, V. M., Giles, T. R., Bobrowsky, P. T., and Matysek, P. F. 1990. Geology of placer deposits in the Cariboo mining district, British Columbia; implications for exploration (93A, B, G, H). Ministry of Energy, Mines and Petroleum Resources, Paper 1990-1: 519-529. 
801 Lian, O. B., and Huntley, D. J. 1999. Optical dating studies of post-glacial aeolian deposits from 802 the south-central interior of British Columbia, Canada. Quaternary Science Reviews, 18: 14538031466.

804 Lian, O.B. and Roberts, R.G. 2006. Dating the Quaternary: Progress in luminescence dating of 805 sediments. Quaternary Science Reviews, 25: 2449 - 2468.

806 Lowden, J.A. and Blake, W.J. 1980. Geological Survey of Canada radiocarbon dates; XX.

807 Geological Survey of Canada, Paper 80-7.

808 Margold, M., Jansson, K., Kleman, J., Stroeven, A., and Clague, J. J. 2013. Late-glacial retreat 809 pattern of the Cordilleran ice sheet in central British Columbia reconstructed from glacial 810 meltwater landforms. Boreas, 42: $830-847$.

811 Mate, D. J. and Levson, V. M. 2001. Quaternary stratigraphy and history of the Ootsa Lake812 Cheslatta River area, Nechako Plateau, central British Columbia. Canadian Journal of Earth 813 Sciences, 38: 751-765.

814 Maynard, D.E., Ward, B.C., Sacco, D.A. and Geertsema, M. 2013a. Terrain Map of Great 815 Beaver Lake map area, British Columbia (NTS 093J/05). Geoscience BC, Map 2013-10-5, scale $816 \quad 1: 50000$.

817 Maynard, D.E., Ward, B.C., Sacco, D.A. and Geertsema, M. 2013b. Terrain Map of Bugle Lake 818 map area, British Columbia (NTS 093J/06). Geoscience BC, Map 2013-10-6, scale 1:50 000.

819 Maynard, D.E., Ward, B.C., Sacco, D.A. and Geertsema, M. 2013c. Terrain Map of Weedon 820 Lake map area, British Columbia (NTS 093J/11). Geoscience BC, Map 2013-10-3, scale 1:50 821000. 
822 McClenaghan, M.B., Bobrowsky, P.T., Hall, G.E.M. and Cook, S.J. (eds). 2000. Drift

823 exploration in glaciated terrain; Geological Society, Special Publication, no. 185, 360 p.

824 Paulen, R.C. and McClenaghan, M.B. (eds). 2013. New frontiers for exploration in glaciated 825 terrain; Geological Survey of Canada, Open File 7374, 81 p.

826 Plouffe, A. 1992. Quaternary stratigraphy and history of central British Columbia. In Current

827 Research, Part A, Geological Survey of Canada, Paper 92-1A: 189 - 193.

828 Plouffe, A. 1997. Ice-flow and late-glacial lakes of the Fraser glaciation, central British

829 Columbia. In Current Research, Geological Survey of Canada, Paper 1997-A/B: 133 - 143.

830 Plouffe, A. 2000. Quaternary geology of the Fort Fraser and Manson River map-areas, central 831 British Columbia. Geological Survey of Canada, Bulletin 554.

832 Plouffe, A. and Levson, V.M. 2001a. Late quaternary glacial and interglacial environments of 833 the Nechako River-Cheslatta Lake area, central British Columbia. Canadian Journal of Earth 834 Sciences, 38: $719-731$.

835 Plouffe, A. and Levson, V.M. 2001b. Surficial geology, Tatelkuz Lake, British Columbia.

836 Geological Survey of Canada, Open-File 4001.

837 Plouffe, A. and Willams, S.P. 1998. Regional till geochemistry, gold and pathfinder elements, 838 northern Nechako River, British Columbia; Geological Survey of Canada, Open File 3687, 3 p, 839 1:400 000 scale, URL

$840<$ http://geoscan.nrcan.gc.ca/starweb/geoscan/servlet.starweb?path=geoscan/downloade.web\&sea $841 \mathrm{rch} 1=\mathrm{R}=210023>[$ September 2012]. 
842 Plouffe, A. and Williams, S.P, 2001. Quaternary geology data Manson River (93N), Fort Fraser 843 (93K) and Nechako River (93F), central British Columbia. Geological Survey of Canada, Open 844 File 2270.

845 Plouffe, A., Bednarski, J.M., Huscroft, C.A., Anderson, R.G, and McCuaig, S.J. 2011. Late 846 Wisconsinan glacial history in the Bonaparte lake map-area, south-central British Columbia; 847 implications for glacial transport and mineral exploration. Canadian Journal of Earth Sciences, $848 \quad 48: 1091-1111$.

849 Prescott, J. and Hutton, J. 1994. Cosmic ray contributions to dose rates for luminescence and 850 ESR dating: Large depths and long term time variations. Radiation Measurements, 23: 497-500.

851 Reading, H. G. (Ed.). 2009. Sedimentary environments: processes, facies and stratigraphy. John 852 Wiley \& Sons.

853 Reimer, P.J., et al. 2013. IntCal13 and Marine 13 radiocarbon age calibration curves 0-50,000 854 years cal BP. Radiocarbon, 55: 1869-1887.

855 Resources Inventory Committee. 1996. Guidelines and standards for terrain mapping in British 856 Columbia. Government of British Columbia, Victoria, B.C.

857 Rutter, N.W. 1974a. Surficial geology and landforms of Williston Lake area (map 2), British 858 Columbia. Geological Survey of Canada, Map 1382A, scale 1:125 000.

859 Rutter, N.W. 1974b. Surficial geology and landforms of Williston Lake area (map 3), British 860 Columbia. Geological Survey of Canada, Map 1383A, scale 1:125 000.

861 Rutter, N.W. 1977. Multiple glaciations in the area of Williston Lake, British Columbia.

862 Geological Survey of Canada, Bulletin 273. 
863 Ryder, J. and Maynard, D. 1991. The Cordilleran Ice Sheet in northern British Columbia.

864 Geographie physique et Quaternaire, 45: 355 - 363.

865 Sacco, D.A. 2012. Quaternary geology in part of the McLeod Lake map area (NTS 093J), central

866 British Columbia. M.Sc. thesis, Department of Earth Sciences, Simon Fraser University,

867 Burnaby, British Columbia.

868 Sacco, D.A., Ward, B.C. and Maynard, D.E. 2013a. Ice flow patterns in NTS 093G, H (west) \&

$869 \mathrm{~J}$ and detailed ice flow history for NTS 093J/05, 06, 11, 12, 13, 14. Geoscience BC, Report 2013-

$870 \quad 08$, scale 1:50 000

871 Sacco, D.A., Ward, B.C., Geertsema, M. and Maynard, D.E. 2013b. Terrain Map of Salmon

872 Lake map area, British Columbia (NTS 093J/13a). Geoscience BC, Map 2013-10-1.

873 Sacco, D.A., Ward, B.C., Geertsema, M. and Maynard, D.E. 2013c. Terrain Map of Carp Lake 874 map area, British Columbia (NTS 093J/14b). Geoscience BC, Map 2013-10-2.

875 Sacco, D.A., Jackaman, W. and Ferbey, T. 2014. Targeted geochemical and mineralogical 876 surveys in the TREK Project area, central British Columbia (parts of NTS 093B, C, F, G); in

877 Geoscience BC Summary of Activities 2013, Geoscience BC, Report 2014-1, p. 19-34.

878 Shaw, J., and Archer, J. 1979. Deglaciation and glaciolacustrine sedimentation conditions, 879 Okanagan Valley, British Columbia, Canada. In Moraines and Varves. Edited by C. Schlüchter. 880 A.A. Balkema, Rotterdam. pp. 347-355.

881 Souther, J.G., Armstrong, R.L., and Harakal, J. 1984. Chronology of the peralkaline, late 882 Cenozoic Mount Edziza Volcanic Complex, northern British Columbia, Canada. Geological 883 Society of America Bulletin, 95: 337 - 349. 
884 Stokes, C.R., Lian, O.B., Tulaczyk, S., Clark, C.D. 2008. Superimposition of ribbed moraines on 885 a paleo-ice-stream bed: implications for ice stream dynamics and shutdown. Earth Surface 886 Processes and Landforms, 33: 593-609.

887 Stumpf, A.J., Broster, B.E., and Levson, V.M. 2000. Multiphase flow of the late Wisconsinan 888 Cordilleran Ice Sheet in western Canada. Bulletin of the Geological Society of America, 112: $8891850-1863$.

890 Tipper, H.W. 1971a. Glacial geomorphology and Pleistocene history of central British 891 Columbia. Geological Survey of Canada, Bulletin 196.

892 Tipper, H.W. 1971b. Multiple glaciations in central British Columbia. Canadian Journal of Earth 893 Sciences, 8: 743-752.

894 van der Meer, J.J.M., Kjaer, K.H., Krueger, J., Rabassa, J., and Kilfeather, A. A. 2009. Under 895 pressure; clastic dykes in glacial settings. Quaternary Science Reviews, 28: 708 - 720.

896 Visser, J.N.J. 1989. Stone orientations in basal glaciogenic diamictite; four examples from the 897 Permo-Carboniferous Dwyka Formation, South Africa. Journal of Sedimentary Petrology, 59: $898935-943$.

899 Ward, B.E., Maynard, D.E., Sacco, D.A. and Geertsema, M. 2013. Terrain Map of Carrier Lake 900 map area, British Columbia (NTS 93J/12). Geoscience BC, Map 2013-10-4, scale 1:50 000.

901 Weary, G.F., Levson, V.M. and Broster, B.E. 1997. Till geochemistry of the Chedakuz Creek 902 map area (93F/7). BC Ministry of Energy and Mines, BC Geological Survey, Open File 1997-11, 90397 p., URL 
$904<$ http://www.empr.gov.bc.ca/Mining/Geoscience/PublicationsCatalogue/OpenFiles/1997/Pages/1 905 997-11.aspx $>$ [October 2013].

906 Woodcock, N.H. and Naylor, M.A. 1983. Randomness testing in three-dimensional orientation 907 data. Journal of Structural Geology, 5: $539-548$.

908 Wintle, A.G. 2008. Luminescence dating: Where it has been and where it is going. Boreas, 37:

$909471-482$.

910 
911 Table 1 Summary of stratigraphic units.

\begin{tabular}{lll}
\hline Unit & Genesis & Geologic event \\
\hline 9 & Aeolian & Post-Fraser Glaciation \\
8 & Glacial (Basal) & Fraser Glaciation (re-advance) \\
7 & Glaciofluvial & Fraser Glaciation (retreat phase) \\
6 & Glaciolacustrine & Fraser Glaciation (retreat phase) \\
5 & Glacial (ablation?) & Fraser Glaciation \\
4 & Glacial (basal) & Fraser Glaciation \\
3 & Glaciolacustrine & Fraser Glaciation (advance phase) \\
2 & Glacial (basal) & Fraser Glaciation (early advance (?)) \\
1 & Glaciolacustrine or glaciofluvial sand & Fraser Glaciation (advance phase) \\
\hline
\end{tabular}

912

913 
914 Table 2 Details for radiocarbon ages discussed in text. See Figure 1 for sample locations.

\begin{tabular}{|c|c|c|c|c|c|c|c|c|}
\hline $\begin{array}{c}\text { Reference } \\
\text { number }\end{array}$ & $\begin{array}{l}\text { Radiocarbon } \\
\text { age (yrs BP) }\end{array}$ & $\begin{array}{c}\text { Calibrated age (yrs } \\
\text { BP) }\end{array}$ & Locality & Material & $\begin{array}{l}\text { Location } \\
\text { (UTM) }\end{array}$ & $\begin{array}{l}\text { UTM } \\
\text { Zone }\end{array}$ & $\begin{array}{l}\text { Sample } \\
\text { Number } \\
\end{array}$ & Reference \\
\hline $\mathrm{RC} 1$ & $8775 \pm 30$ & $9910-9640$ & Hart, BC & $\begin{array}{c}\text { peat from esker } \\
\text { system }\end{array}$ & $\begin{array}{c}515094, \\
59779763\end{array}$ & 10 & $\begin{array}{c}\text { UCAIMS- } \\
83989\end{array}$ & This study \\
\hline $\mathrm{RC} 2$ & $9440 \pm 110$ & $11140-10400$ & Skunk Lake & $\begin{array}{l}\text { peat overlying } \\
\text { glacial sediment }\end{array}$ & $\begin{array}{l}430319 \\
6141989\end{array}$ & 10 & $\begin{array}{l}\text { GSC- } \\
5869\end{array}$ & Plouffe 2000 \\
\hline $\mathrm{RC} 3$ & $9830 \pm 130$ & $11760-10780$ & Nautley River & $\begin{array}{l}\text { peat overlying } \\
\text { glacial sediment }\end{array}$ & $\begin{array}{l}396118 \\
6000514\end{array}$ & 10 & $\begin{array}{l}\text { GSC- } \\
5891\end{array}$ & Plouffe 2000 \\
\hline $\mathrm{RC4}$ & $10000 \pm 140$ & $12040-11200$ & $\begin{array}{c}\text { Omineca } \\
\text { Valley }\end{array}$ & $\begin{array}{c}\text { peat overlying } \\
\text { glacial sediment }\end{array}$ & $\begin{array}{l}368628 \\
6184920\end{array}$ & 10 & $\begin{array}{l}\text { GSC- } \\
2036-2\end{array}$ & Blake 1986 \\
\hline RC5 & $10100 \pm 90$ & $12040-11320$ & $\begin{array}{l}\text { Omineca } \\
\text { Valley }\end{array}$ & $\begin{array}{l}\text { marl overlying } \\
\text { glacial sediment }\end{array}$ & $\begin{array}{l}368628 \\
6184920\end{array}$ & 10 & $\begin{array}{l}\text { GSC- } \\
2036\end{array}$ & $\begin{array}{c}\text { Alley and } \\
\text { Young } 1978\end{array}$ \\
\hline
\end{tabular}

$915{ }^{a}$ Calibration range is 2s. Calibration was done using OxCal 4.2 (Brock-Ramsey 2009) and the

916 IntCal13 data set (Reimer et al. 2013).

917 
918 Table 3 Dose rates, equivalent doses and optical ages. See Figure 2 for sample locations.

\begin{tabular}{lllll}
\hline Sample & $\dot{D}_{c}(\mathrm{~Gy} / \mathrm{ka})^{a}$ & $\dot{D}_{\mathrm{T}}(\mathrm{Gy} / \mathrm{ka})^{b}$ & $D_{\mathrm{e}}(\mathrm{Gy})^{c}$ & ${\text { Optical age }(\mathrm{ka})^{d}}^{c}$ \\
\hline OCDF5 (feldspar) & $0.154 \pm 0.0077$ & $2.17 \pm 0.15$ & $17.6 \pm 0.2$ & $9.94 \pm 0.77$ \\
OCDF5 (quartz) & $0.154 \pm 0.0077$ & $1.79 \pm 0.11$ & $15.7 \pm 0.7$ & $8.79 \pm 0.51$ \\
OCDF4 (feldspar) & $0.161 \pm 0.008$ & $2.21 \pm 0.14$ & $23.8 \pm 0.5$ & $13.3 \pm 1.0$ \\
CLR5 (feldspar) & $0.163 \pm 0.0082$ & $3.27 \pm 0.2$ & $26.4 \pm 0.3$ & $9.35 \pm 0.64$ \\
\hline
\end{tabular}

$919{ }^{a} \dot{D} \mathrm{c}:$ dose rate due to cosmic rays, calculated using present day burial depths and the

920 relationship of Prescot and Hutton (1994).

$921{ }^{b} \dot{D}_{\mathrm{T}}$ : total dose rates due to cosmic rays and $\alpha, \beta$ and $\gamma$ radiation.

$922{ }^{c} D_{\mathrm{e}}$ : equivalent dose found using the central age model.

$923{ }^{d}$ Apparent optical ages (feldspar ages corrected for AF) and their analytical uncertainties at $\pm 1 \sigma$. 
925 Table 4 Till clast fabric details. Refer to figure 7 for locations.

\begin{tabular}{cccccccc}
\hline $\begin{array}{l}\text { Fabric } \\
\text { number }\end{array}$ & $\begin{array}{c}\text { Depth from } \\
\text { surface }(\mathrm{m})\end{array}$ & $\begin{array}{l}\text { Clasts } \\
\text { measured }\end{array}$ & $\begin{array}{l}\text { Site } \\
\text { Number }\end{array}$ & Eigenvector $\left(^{\circ}\right)$ & $\begin{array}{l}\text { Mean } \\
\text { plunge }\end{array}$ & $\begin{array}{c}\text { Apparent ice flow } \\
\text { direction }\left({ }^{\circ}\right)^{a}\end{array}$ & Eigenvalue 1 \\
\hline $09-01$ & 3 & 50 & 1 & 172 & 1 & 352 & 0.689 \\
$09-02$ & 1.75 & 50 & 2 & 205 & 7 & 25 & 0.822 \\
$09-03$ & 2 & 50 & 3 & 170 & 14 & 350 & 0.788 \\
$09-05$ & 2 & 50 & 4 & 261 & 0 & 81 & 0.720 \\
$09-06$ & 1.75 & 50 & 5 & 229 & 1 & 49 & 0.683 \\
$10-01$ & 2.1 & 25 & 6 & 224 & 9 & 44 & 0.780 \\
$10-02$ & 1.2 & 25 & 6 & 268 & 4 & 88 & 0.809 \\
$11-01$ & 2 & 30 & 7 & 61 & 0 & 241 & 0.819 \\
$11-02$ & 3.5 & 30 & 7 & 202 & 8 & 22 & 0.722 \\
$11-03$ & 4 & 50 & 8 & 204 & 15 & 24 & 0.846 \\
$11-04$ & 2 & 50 & 8 & 211 & 11 & 31 & 0.880 \\
$11-05$ & 2.75 & 30 & 9 & 240 & 5 & 60 & 0.745 \\
$11-06$ & 1.5 & 35 & 9 & 61 & 8 & 241 & 0.465 \\
\hline
\end{tabular}

927 from inferred ice flow direction (see text). 
929 Figure 1 a) Location map showing the study area (grey box) within the Interior Plateau

930 physiographic region (dashed line; after Holland (1976)) of British Columbia with locations of

931 radiocarbon ages (green symbol) and place names referred to in the text. b) Physiography and

932 local place names of the study area which comprises NTS map areas 093J05/06/11/12/13/14.

933 Major forest service roads are shown by thin black lines. Shaded relief derived from Canadian

934 digital elevation data (Geobase $\left.{ }^{\circledR} 2009\right)$.

935

936 Figure 2 a) Simplified surficial geology for the study area based on terrain mapping. Locations

937 of logged stratigraphic sections are indicated by red stars and aeolian samples for optical dating

938 by yellow stars. The original maps can be found at http://www.geosciencebc.com/s/Report2013-

939 10.asp. Examples of landforms used to determine the glacial history: b) streamlined macroforms;

940 c) subglacial meltwater complex; d/e) ice-contact glaciofluvial deposits; f/g). meltwater

941 channels. Orthophotography base processed from imagery collected in 1996 and 1997.

942

$943 \quad$ Figure 3 Representative stratigraphic $\operatorname{logs}$ from the study area. See Figure 2 for locations.

945 Figure 4 a) Lower part of section DS-01 exposing subaqueous outwash fan sediments (unit 1c)

946 below an early advance till (unit 2). Scale is approximate. Insets show: b) undulating,

947 interstratified sand, gravel and diamict beds in unit 1c with approximate scale; and c) dewatering

948 structures in the upper sand beds of unit 1c (dashed line) with scale increments of $1 \mathrm{~cm}$. 
950 Figure 5 Modified SAR methods used to date feldspar (a) and quartz (b) fractions of samples. $\mathrm{L}_{\mathrm{i}}$

951 is the luminescence measured after administration of a regenerative dose, $D_{i}$. Regenerative doses

952 ( $\mathrm{i}=1$ to 5$)$ for feldspar were $6.55,13.1,26.2,52.4$ and 0 Gy and quartz 4.98, 9.97, 19.93, 39.87

953 and $0 \mathrm{~Gy}$; the $0 \mathrm{~Gy}$ data point is used to check for thermal transfer resulting from the preheat,

954 which lasted for $10 \mathrm{~s}$ at $180^{\circ} \mathrm{C}$ for feldspar and $240^{\circ} \mathrm{C}$ for quartz. $\mathrm{T}_{\mathrm{i}}$ is the luminescence

955 measured after a test dose of $0.87 \mathrm{~Gy}$ at a cut-heat of $160^{\circ} \mathrm{C}$ and $14.95 \mathrm{~Gy}$ at a cut-heat of $220^{\circ}$

$956 \mathrm{C}$ for feldspar and quartz respectively. A higher $\mathrm{D}_{\mathrm{t}}$ was used for quartz due to the limited

957 luminescence produced from the grains. The 13.1 Gy (feldspar) and 9.97 Gy (quartz) doses were

958 repeated for each aliquot to determine the effectiveness of the test dose for correcting for

959 sensitivity change. Typical examples of luminescence decay curves for aliquots from OCDF4 (c;

960 feldspar) and OCDF5 (d; quartz). Inset graphs show the dose-response data for these aliquots,

961 determined from the sensitivity corrected luminescence $\left(\mathrm{L}_{\mathrm{i}} / \mathrm{T}_{\mathrm{i}}\right)$ measured over the first $0.4 \mathrm{~s}$ of

962 stimulation. The data are fitted with a saturating exponential curve, onto which the natural

963 luminescence is interpolated in order to determine the equivalent dose (De).

Figure 6 Locations and orientations of macroforms and striations discussed in text. Some

966 macroforms were removed when plotting where symbol concentrations were high. Striation data

967 indicate early southeastward ice flow (green symbols), general northeast ice flow at glacial

968 maximum (black symbols) and eastward flow in the late glacial period (red symbols). Orange

969 circle refers to striation sequence discussed in text.

971 Figure 7 Locations and measurements of till clast fabrics. Stereonet plots use a Schmidt equal

972 area projection in the lower hemisphere. Refer to Table 4 for fabric details. 
974 Figure 8 Glacier and drainage networks during deglaciation. Successive ice margins are 975 hypothesized based on the trend of successive lateral meltwater channels. a) Near complete ice 976 cover; subglacial meltwater flowing northeast. b) Linear ice margin retreating into study area;

977 lateral meltwater channels forming; proglacial meltwater flowing northeast into glacial Lake 978 McLeod. c) Linear ice margin continues to retreat; ice marginal lakes develop against uplands in 979 north and around Weadon Lake in south. d) Ice margin retreats past drainage divide; proglacial 980 meltwater drains southeast. e) Ice margin trending more north-south in the west and east-west in 981 the south; proglacial meltwater continues to drain southeast; glacial lakes develop around Great 982 Beaver Lake and in the southeast.

Figure 9 Inferred configurations of glacial Lake McLeod. a) Minimum water-level elevation for 985 the maximum extent is determined from a spillway draining east into the Parsnip River valley, 986 and a south-dipping ice-marginal channel cut into the east valley wall at $\sim 750 \mathrm{~m}$ a.s.1. b) Second

987 extent at a minimum water-level elevation of $\sim 690 \mathrm{~m}$ a.s.l. inferred from the elevation of delta 988 topsets at the mouth of the McLeod River valley. Glacial Lake Fraser drained into glacial Lake McLeod at this stage.

Figure 10 Glacial Lake Fraser delineated at a water level of $715 \mathrm{~m}$ a.s.1 that was controlled by a 992 spillway into the Peace River watershed. Glaciolacustrine sediments could not have been 993 deposited contemporaneously at the depicted extents (light blue lines from Plouffe (2000); brown 994 from this study; purple from Sacco et al. (2014); red from Clague (1998a); and dark blue from 995 Tipper (1971b)). Therefore, this map suggests that a glacial lake complex consisting of non- 
996 contemporaneous lakes occupied a large part of the region. The configuration of the complex 997 was likely time-transgressive and the extent and elevation of the lakes were in part controlled by 998 retreating glaciers that obstructed the drainage.

1000 Figure 11 Hypothetical ice configuration used to explain glacial Lake Stuart at a water level of $1001780 \mathrm{~m}$ a.s.l., and the formation of the Prince George esker system. Glacial Lake Fraser is 1002 depicted at a water level of $715 \mathrm{~m}$ a.s.1., which was controlled by the outlet draining north in to 1003 the Peace River watershed. Location of organics analysed by radiocarbon dating indicated by 1004 black symbol. See text for details.

Figure 12 Regional ice-flow model for the northern Interior with data from Tipper (1971a);

1007 Plouffe (2000); Stumpf et al. (2000); Levson (2001); Plouffe and Levson (2001b) and this study. 1008 Physiographic regions after Holland (1976). Field area of this study is outlined in red. a) Glaciers 1009 first flowed southeast from the Omineca Mountains (green arrows) until more dominant ice from 1010 the west, south and southeast deflected the flow direction to the northeast (yellow and blue 1011 arrows). b) During the maximum phase, the ice divide shifted east from the Coast Mountains. Ice 1012 flow maintained a dominantly northeastern flow direction over most of the northern Interior 1013 Plateau, while reversing direction west of the divide (black arrows). c) During the late glacial 1014 phase, ice flow was initially modified by topography on the foothills of the Rocky Mountains 1015 until it retreated (orange arrows). The influence from the south diminished and the glaciers 1016 sourced in the west became dominant causing an eastward shift in ice flow (red arrows). 
1018 Appendix A: Optical dating sample collection and preparation procedures

1019 Samples were collected by inserting an opaque ABS tube $(\sim 15 \mathrm{~cm}$ long and $\sim 8 \mathrm{~cm}$ in diameter $)$

1020 into a freshly exposed vertical section. Zones with evidence of bioturbation or other post-

1021 depositional disturbances were avoided as these processes can introduce grains with different

1022 light exposure histories to the sample. All sample tubes were completely filled with material to

1023 keep the contents immobile and the slip caps were reinforced with duct tape to provide an air-

1024 tight seal to retain the as-collected water contents.

1025 Under filtered light in the laboratory, all samples were sub-sampled to determine water content.

1026 The as-collected, saturated and dry weights were used to calculate the as-collected and saturated

1027 water contents. For each sample, about $20 \mathrm{~g}$ of sediment was removed, dried and milled, and sent

1028 to a commercial laboratory where $\mathrm{U}$, Th, and $\mathrm{K}$ concentrations were determined, which are

1029 needed to calculate environmental dose rates. Material from the centre of the tube was extracted

1030 for optical dating.

1031 Coarse-grained quartz $(180-250 \mu \mathrm{m})$ and fine-grained feldspar $(4-11 \mu \mathrm{m})$ were isolated from all

1032 processed samples for dating. Quartz was chosen because it is highly resistant to weathering and

1033 requires less exposure to sunlight to empty electron traps and effectively reset the 'luminescence

1034 clock'. However, in some cases quartz may not emit measurable luminescence (Lian 2013).

1035 Feldspar produces a higher intensity luminescence signal, but it suffers from anomalous fading

1036 (discussed below). To mitigate this effect, the fine-grained size fraction of feldspar was used, as

1037 it is thought to be less susceptible to anomalous fading (Lian and Roberts 2006).

1038 Material extracted for dating was first treated with a $10 \% \mathrm{HCl}$ solution to dissolve any

1039 carbonates and then was wet-sieved using deionized water to isolate the $180-250 \mu \mathrm{m}$ size 
1040 fraction; the fine-grained fraction was set aside for the feldspar experiments. Quartz and feldspar 1041 were separated from heavier minerals using a sodium polytungstate solution with a density of $10422.72 \mathrm{~g} \mathrm{ml}-1$. Using a centrifuge, quartz and feldspar were then separated from each other in a 1043 sodium polytungstate solution with a density of $2.6 \mathrm{~g} \mathrm{ml}-1$. The quartz grains were subsequently 1044 exposed to a $48 \%$ HF solution for 40 minutes to etch away alpha-affected surfaces and to 1045 dissolve any remaining feldspar grains.

1046 The retained fine-grained polymineral fractions were treated with $10 \% \mathrm{H}_{2} \mathrm{O}_{2}$ to remove any 1047 organic matter that might have been present. The sediment was then deflocculated by adding a 1 1048 g L-1 solution of sodium hexametaphosphate and mechanically agitating the slurry on a shaker 1049 table. The 4-11 $\mu \mathrm{m}$ size fraction was isolated using the Stokes settling technique that is based on 1050 particle settling rates in a column of water. The $>11 \mu \mathrm{m}$ size fraction was removed by allowing 1051 the sediment to settle in a $20 \mathrm{~cm}$ column of water for 30 minutes and discarding the any settled $1052(>11 \mu \mathrm{m})$ material. The $<4 \mu \mathrm{m}$ size fraction was removed by allowing the sediment to settle for 4 1053 hours and discarding the material still in suspension $(<4 \mu \mathrm{m})$.

1054 Individual aliquots from each coarse-grained subsample were made by sprinkling about 100 1055 grains of quartz on 9.8-mm diameter aluminium discs using silicone oil as an adhesive. Aliquots 1056 of fine-grained sediments were made by suspending the 4-11 $\mu \mathrm{m}$ size fraction in acetone and 1057 pipetting $1 \mathrm{ml}$ of the solution into vials with aluminum discs placed at their bottoms and allowing 1058 the acetone to evaporate.

1059 Environmental dose rate determination

1060 Environmental radiation absorbed by the samples after burial comes from alpha, beta and gamma 1061 radiation produced by the decay of $\mathrm{U}, \mathrm{Th}$, their daughter products, and $40 \mathrm{~K}$ in the sediment 
1062 grains and in the surrounding environment. There is also a contribution from cosmic rays which 1063 decreases with depth beneath the ground surface. Subsamples extracted for dosimetry were sent 1064 to Becquerel Laboratories (Mississauga, Ontario) for neutron-activation analysis to determine the 1065 element contents (Table A1). Environmental dose rates were calculated using standard formulae 1066 (Aitken 1985; Lian et al. 1995) and the dose rate conversion factors of Adameic and Aitken 1067 (1998). Pore water within the sediment attenuates or absorbs radiation differently from mineral 1068 matter and therefore must be accounted for in dose rate calculations. For each sample the as1069 collected water contents were used because it is unlikely that the well-drained sand-rich aeolian 1070 sediment was ever water-saturated (Table A1). A 10\% uncertainty was included with each water 1071 content value to account for periodic wet or dry conditions. The contribution from cosmic rays 1072 was determined using the current burial depths and the formulae given by Prescott and Hutton 1073 (1994) (Table A2).

1074 Equivalent dose determination

1075 Equivalent dose (De) determinations were carried out with a Risø TL/OSL-DA-20 reader 1076 equipped with a $90 \mathrm{Sr} / 90 \mathrm{Y}$ beta source that delivered $5.98 \pm 0.12 \mathrm{~Gy} / \mathrm{min}$ to coarse-grain samples 1077 and $5.24 \pm 0.12 \mathrm{~Gy} / \mathrm{min}$ to fine-grain samples. Quartz grains were stimulated using light-emitting 1078 diodes that delivered $45 \mathrm{~mW} \mathrm{~cm}-2$ of blue $(470 \mathrm{~nm})$ light to the sample aliquot; the luminescence 1079 measured was ultraviolet $(\sim 350 \mathrm{~nm})$ detected by an Electron Tubes Ltd. 9235QB photomultiplier 1080 tube placed behind a single 7.5 mm-thick Hoya U-340 optical filter. Potassium feldspar on the 1081 polymineral fine-grained aliquots was stimulated preferentially using light-emitting diodes that 1082 delivered $135 \mathrm{~mW} \mathrm{~cm}-2$ of infrared $(870 \mathrm{~nm})$ light; the luminescence characteristic of $\mathrm{K}$ 1083 feldspars ( 400 nm) was isolated using a Kopp 7-59 optical filter. A Schott BG-39 filter was 
1084 used to absorb scattered infrared light. The photomultiplier tube was the same as that used for 1085 quartz.

1086 A series of pilot De determination experiments were first conducted on 5-10 aliquots from each 1087 sample to determine the best measurement protocols. The pilot experiments indicated that quartz 1088 from samples OCDF4 and CLR5 is not suitable for dating because the measured luminescence 1089 was too dim or the samples behaved poorly (e.g. aliquots frequently failed recycling tests and/or 1090 their luminescence signal did not appear to consist of the desired fast component; see below). 1091 Pilot tests using K-feldspar from sample MLD1 yielded a preliminary age value of $\sim 75 \mathrm{ka}$, 1092 suggesting that mineral grains with different light exposure histories, possibly glaciofluvial, were 1093 inadvertently sampled, so no further analysis was done on quartz or feldspar from this sample.

1094 For all of the other samples, De values were determined using a standard single-aliquot 1095 regenerative-dose (SAR) procedure (Murray and Wintle 2000; see Figure A1 for procedure 1096 details). Two additions were made to the procedure for quartz: 1) grains were treated with an 1097 infrared wash prior to the measurement of luminescence (Figure A1b, step 3); and 2) after the 1098 measurement of luminescence from the test dose, aliquots were treated with an additional blue 1099 light stimulation at a higher temperature than the first preheat (Figure A1b, step 9). The infrared 1100 wash removes any signal from feldspar contamination (Wintle and Murray 2006), which was 1101 only minor when it occurred. The additional blue light stimulation is intended to reduce the 1102 effect of thermal transfer of electrons from optically insensitive traps to optically sensitive traps 1103 that occurred during the second preheat (Figure A1b, step 6; Murray and Wintel 2003). The SAR 1104 protocol used for the fine-grained feldspar samples was based on one found to be successful in 1105 dating the same mineral and particle sizes from aeolian samples of known age near Clinton in the 1106 Southern Interior of British Columbia (W.L. Moon, pers. comm. 2011; see Figure A1 for 
1107 procedure details). For both minerals, a zero-dose point was included in construction of the dose-

1108 response curves to assess the severity of preheat-induced thermal transfer and one of the

1109 regenerative-dose points was repeated to assess the efficacy of the test dose to correct for

1110 sensitivity changes. The luminescence measured over the first $0.4 \mathrm{~s}$ of excitation was used to

1111 construct dose-response curves from which the De was determined by interpolation (Figure A1c,

1112 d). Aliquots were rejected for De determination if the luminescence measured at the 0 Gy step

1113 was above $5 \%$ of the natural signal or if the recycling ratio (repeated dose) was greater than 10

$1114 \%$ of unity. De values for the accepted aliquots from each sample were plotted on radial plots,

1115 and the central age model (Galbraith et al. 1999) was used to determine the weighted mean

1116 equivalent doses used to calculate the optical ages (Figure A2; Table A2).

1117 Dose recovery experiments were performed on some of the samples to test the adequacy of the

1118 chosen SAR protocol (Murray and Wintle 2003; Wintle and Murray 2006). The dose recovery

1119 procedure involved exposing a number of aliquots to sunlight to empty relevant electron traps. A

1120 known laboratory dose, similar to the sample's De, was then given to the aliquots and the same

1121 SAR protocol used for the De determination was used to attempt to recover this dose. If the SAR

1122 protocol is working correctly and if the mineral is suitable for optical dating (i.e., it does not

1123 exhibit anomalous luminescence properties; cf. Demuro et al. 2008), the procedure should be

1124 able to recover the laboratory dose. For quartz, a successful dose recovery test may also indicate

1125 that the luminescence measured is dominated by that arising from the thermally-stable fast

1126 component of a sample's luminescence signal, and that there is not a significant contribution

1127 from the thermally unstable slow and medium components. Less is known about the structure of

1128 the luminescence emitted from infrared-stimulated K-feldspar, but it is likely that it arises from a

1129 continuum of traps that are thermally stable (Wintle 2008). Measurements on known-aged 
1130 samples appear to confirm this hypothesis if anomalous fading is taken into account. Anomalous

1131 fading refers to the loss of electrons in thermally stable traps due to quantum mechanical

1132 tunnelling of electrons from the traps of interest to traps that are thermally unstable over

1133 geological time (Huntley and Lamothe 2001). If not corrected for, anomalous fading can cause

1134 erroneously low De determinations and result in calculated optical ages that are too young. Thus,

1135 any discrepancy in the dose recovery test for K-feldspar can be attributed to the choice of an

1136 inadequate SAR protocol, or to AF if there is a delay between irradiation and measurement. The

1137 effect of the latter is best observed if a significant delay is made between laboratory irradiation

1138 and measurement.

1139 The dose recovery test for the quartz fraction of sample OCDF5 consisted of 20 aliquots exposed

1140 to sunlight for 30 minutes and subsequently given a beta dose of $19.7 \pm 0.7$ Gy (a value close to

1141 its pre-determined De). After 3 days, the aliquots were measured using the same SAR protocol

1142 originally used to date the sample. A dose of $13.9 \pm 0.7(\sim 70 \%)$ was recovered, suggesting that

1143 the luminescence signal of the quartz is significantly influenced by the thermally unstable

1144 medium and/or slow components.

1145 Dose recovery tests were conducted on feldspar samples CLR5 and OCDF4. For CLR5, 20

1146 aliquots exposed to sunlight for $30 \mathrm{~min}$ and subsequently given a beta dose of $26.0 \pm 0.5 \mathrm{~Gy}$;

1147 after 44 days, a dose of $25.0 \pm 0.2$ Gy was recovered. For OCDF4, 38 aliquots were given a

1148 similar exposure to sunlight and a beta dose of $17.3 \pm 0.4 \mathrm{~Gy}$; after a delay of one day, 20 were

1149 measured and a dose of $16.1 \pm 0.2$ Gy was recovered. The remaining 18 aliquots were measured

1150 after a period of 425 days, and the difference in the recovered dose was negligible (within the

1151 uncertainties of the measurement). Both dose-recovery tests are in agreement, and suggest that a

1152 fading rate of no more than $2.0 \pm 0.5 \%$ per decade (cf. Huntley and Lamothe 2001) must be 
1153 applied to correct for AF in the fine-grained K-feldspar fraction of these samples. Based on the 1154 success of the experiments, using the same SAR protocol, on aeolian material in the lower Fraser 1155 River valley (unpublished results), it is unlikely that a significant part of the small difference in 1156 given and recovered dose was due to a minor inadequacy of the chosen SAR protocol. However, 1157 more fading tests should be done to confirm this assertion as the samples dated in this 1158 experiment and those from the lower Fraser River valley are about $300 \mathrm{~km}$ apart.

1159 Appendix A References

1160 Adamiec, G. and Aitken, M.J. 1998. Dose-rate conversion factors: update. Ancient TL, 16: 37 116139.

1162 Aitken, M.J. 1985. Thermoluminescence dating. Academic Press, New York.

1163 Demuro, M., Roberts, R., Froese, D., Arnold, L., Brock, F., and Bronk Ramsey, C. 2008.

1164 Optically stimulated luminescence dating of singe and multiple grains of quartz from perennially 1165 frozen loess in western Yukon Territory, Canada: Comparison with radiocarbon chronologies for 1166 the late Pleistocene Dawson tephra. Quaternary Geochronology, 3: 346-364.

1167 Galbraith, R.F. Roberts, R.G., Laslett, G.M., Yoshida, H. and Olley, J.M. 1999. Optical dating of 1168 single and multiple grains of quartz from Jinmium rock shelter, northern Australia, part 1, 1169 experimental design and statistical models. Archaeometry, 41: $339-364$.

1170 Huntley, D. J. and Lamothe, M. 2001. Ubiquity of anomalous fading in K-feldspars and the 1171 measurement and correction for it in optical dating. Canadian Journal of Earth Sciences, 38: $11721093-1106$. 
1173 Lian, O.B. 2013. Optical Dating. In: Elias S.A. (ed). The Encyclopedia of Quaternary Science, 1174 vol 2: pp. 653-666.

1175 Lian, O. B. and Roberts, R. 2006. Dating the Quaternary: Progress in luminescence dating of 1176 sediments. Quaternary Science Reviews, 25: 2449 - 2468.

1177 Lian, O.B., Hu, J., Huntley, D.J., and Hicock, S.R. 1995. Optical dating studies of Quaternary 1178 organic-rich sediments from southwestern British Columbia and northwestern Washington State. 1179 Canadian Journal of Earth Sciences, 32: 1194 - 1207.

1180 Murray, A. S. and Wintle, A. G. 2000. Luminescence dating of quartz using an improved single1181 aliquot regenerative-dose protocol. Radiation Measurements, 32: 57-73.

1182 Murray, A.S. and Wintle, A.G. 2003. The single aliquot regenerative dose protocol; potential for 1183 improvements in reliability. Radiation Measurements, 37: 377-381.

1184 Prescott, J. and Hutton, J. 1994. Cosmic ray contributions to dose rates for luminescence and 1185 ESR dating: Large depths and long term time variations. Radiation Measurements, 23: 497-500.

1186 Wintle, A. G. 2008. Luminescence dating: Where it has been and where it is going. Boreas, 37: $1187 \quad 471-482$.

1188 Wintle, A. G. and Murray, A. S. 2006. A review of quartz optically stimulated luminescence 1189 characteristics and their relevance in single-aliquot regeneration dating protocols. Radiation 1190 Measurements, 41: 369-391. 
1192 Table A1 Sample depths, K, U, Th and water contents.

\begin{tabular}{llllll}
\hline Sample & $d(\mathrm{~cm})^{\mathrm{a}}$ & $\mathrm{K}(\%)^{\mathrm{b}}$ & $\mathrm{U}(\mathrm{ppm})^{\mathrm{b}}$ & $\mathrm{Th}(\mathrm{ppm})^{\mathrm{b}}$ & $\Delta^{\mathrm{wc}}$ \\
\hline OCDF5 (feldspar) & 180 & $1.33 \pm 0.07$ & $1.2 \pm 0.13$ & $2.6 \pm 0.09$ & $0.076 \pm 0.008$ \\
OCDF5 (quartz) & 180 & $1.33 \pm 0.07$ & $1.2 \pm 0.13$ & $2.6 \pm 0.09$ & $0.076 \pm 0.008$ \\
OCDF4 (feldspar) & 155 & $1.4 \pm 0.1$ & $0.9 \pm 0.11$ & $2.7 \pm 0.12$ & $0.047 \pm 0.005$ \\
CLR5 (feldspar) & 145 & $2.07 \pm 0.08$ & $1.3 \pm 0.14$ & $4.8 \pm 0.16$ & $0.046 \pm 0.005$ \\
\hline
\end{tabular}

${ }^{\mathrm{a}} d$ : sample depth beneath the ground surface.

$1194{ }^{\mathrm{b}} \mathrm{K}, \mathrm{U}$ and Th contents were determined using neutron-activation analysis.

$1195{ }^{\mathrm{c}} \Delta^{\mathrm{w}}$ : water content $=$ water mass/mineral mass. As collected water contents with a $10 \%$ error 1196 applied were used for calculations. 
1198 Table A2 Dose rates, equivalent doses and optical ages.

\begin{tabular}{lllll}
\hline Sample & $\dot{D}_{c}(\mathrm{~Gy} / \mathrm{ka})^{\mathrm{a}}$ & $\dot{D}_{\mathrm{T}}(\mathrm{Gy} / \mathrm{ka})^{\mathrm{b}}$ & $D_{\mathrm{e}}(\mathrm{Gy})^{\mathrm{c}}$ & ${\text { Optical age }(\mathrm{ka})^{\mathrm{d}}}^{\mathrm{d}}$ \\
\hline OCDF5 (feldspar) & $0.154 \pm 0.0077$ & $2.17 \pm 0.15$ & $17.6 \pm 0.2$ & $9.94 \pm 0.77$ \\
OCDF5 (quartz) & $0.154 \pm 0.0077$ & $1.79 \pm 0.11$ & $15.7 \pm 0.7$ & $8.79 \pm 0.51$ \\
OCDF4 (feldspar) & $0.161 \pm 0.008$ & $2.21 \pm 0.14$ & $23.8 \pm 0.5$ & $13.3 \pm 1.0$ \\
CLR5 (feldspar) & $0.163 \pm 0.0082$ & $3.27 \pm 0.2$ & $26.4 \pm 0.3$ & $9.35 \pm 0.64$ \\
\hline
\end{tabular}

$1199{ }^{\mathrm{a}} \dot{D} \mathrm{c}:$ dose rate due to cosmic rays, calculated using present day burial depths and the

1200 relationship of Prescot and Hutton (1994).

$1201{ }^{\mathrm{b}} \dot{D}_{\mathrm{T}}$ : total dose rates due to cosmic rays and $\alpha, \beta$ and $\gamma$ radiation.

$1202{ }^{\mathrm{c}} D_{\mathrm{e}}$ : equivalent dose found using the central age model.

$1203{ }^{d}$ Apparent optical ages (felspar ages corrected for AF) and their analytical uncertainties at $\pm 1 \sigma$. 
1206 Figure A1 Modified SAR methods used to date feldspar (a) and quartz (b) fractions of samples.

$1207 \mathrm{Li}$ is the luminescence measured after administration of a regenerative dose, Di. Regenerative

1208 doses $(i=1$ to 5$)$ for feldspar were 6.55, 13.1, 26.2, 52.4 and 0 Gy and quartz 4.98, 9.97, 19.93,

120939.87 and $0 \mathrm{~Gy}$; the $0 \mathrm{~Gy}$ data point is used to check for thermal transfer resulting from the

1210 preheat, which lasted for $10 \mathrm{~s}$ at $180^{\circ} \mathrm{C}$ for feldspar and $240^{\circ} \mathrm{C}$ for quartz. Ti is the

1211 luminescence measured after a test dose of $0.87 \mathrm{~Gy}$ at a cut-heat of $160^{\circ} \mathrm{C}$ and 14.95 Gy at a cut-

1212 heat of $220^{\circ} \mathrm{C}$ for feldspar and quartz respectively. A higher Dt was used for quartz due to the

1213 limited luminescence produced from the grains. The 13.1 Gy (feldspar) and 9.97 Gy (quartz)

1214 doses were repeated for each aliquot to determine the effectiveness of the test dose for correcting

1215 for sensitivity change. Typical examples of luminescence decay curves for aliquots from

1216 OCDF4 (c; feldspar) and OCDF5 (d; quartz). Inset graphs show the dose-response data for these

1217 aliquots, determined from the sensitivity corrected luminescence (Li/Ti) measured over the first

$12180.4 \mathrm{~s}$ of stimulation. The data are fitted with a saturating exponential curve, onto which the

1219 natural luminescence is interpolated in order to determine the equivalent dose (De).

1220 Figure A2 Radial plots showing the distribution of equivalent doses from each sample. More

1221 precise data plot farther from the origin. The gray bands are centred on the weighted mean

1222 equivalent dose values provided by the central age model and encompass aliquots with

1223 equivalent doses consistent with the mean at a $95 \%$ confidence interval. 


\section{Page 63 of 76}

\section{Canadian Journal of Earth Sciênces}

$123^{\circ} \mathrm{W}$

$\prod_{s}^{N}$

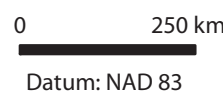

Datum: NAD 83
Projection: PC Albers

Physiographic
region

- City

Radiocarbon age

(see Table 2 for details)

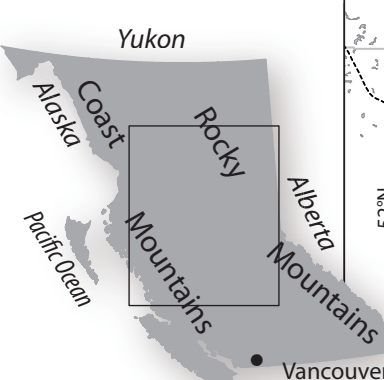

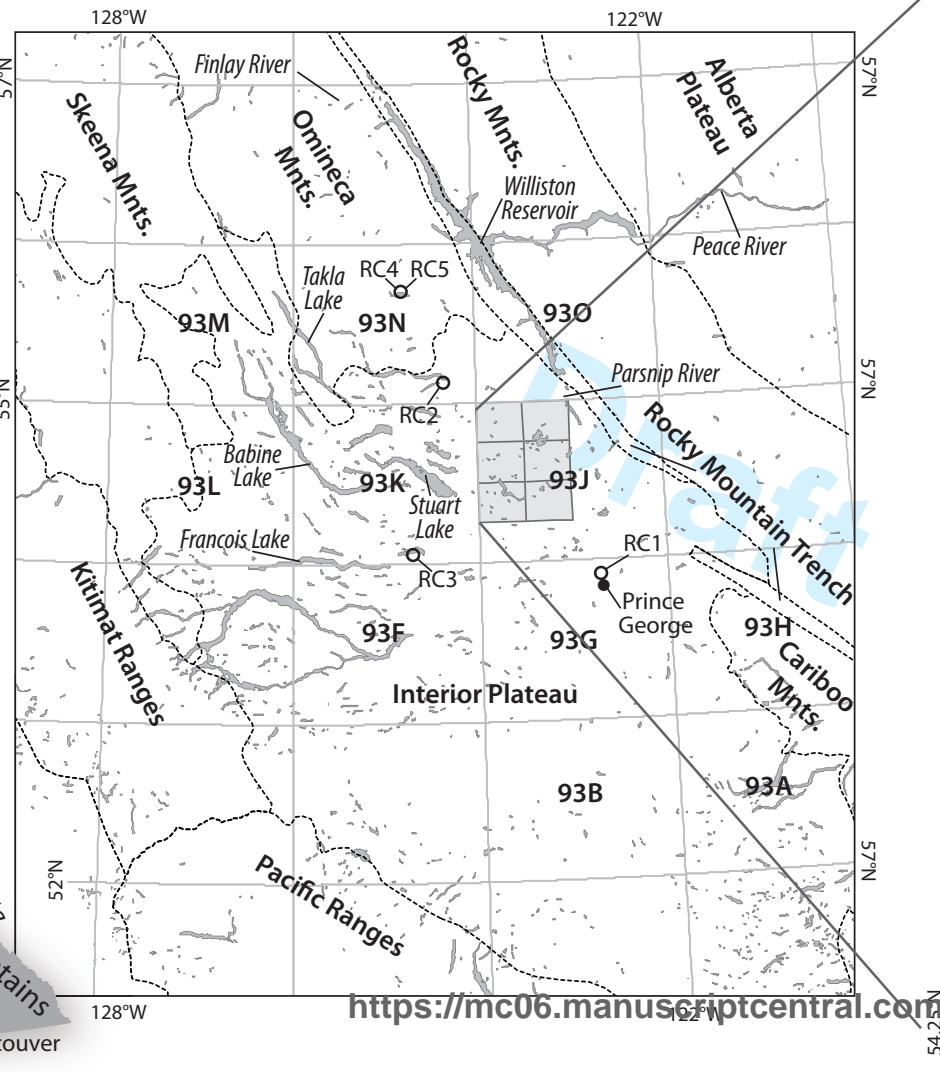

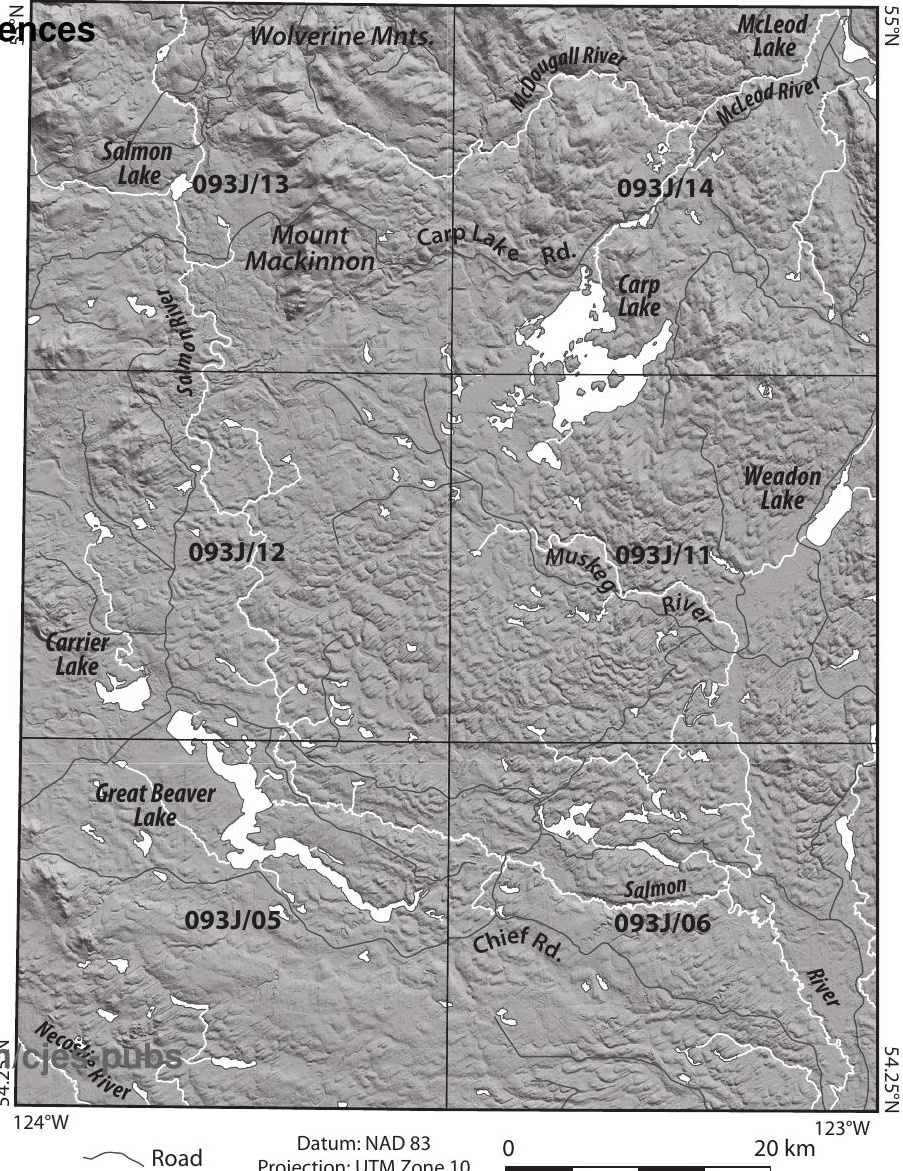




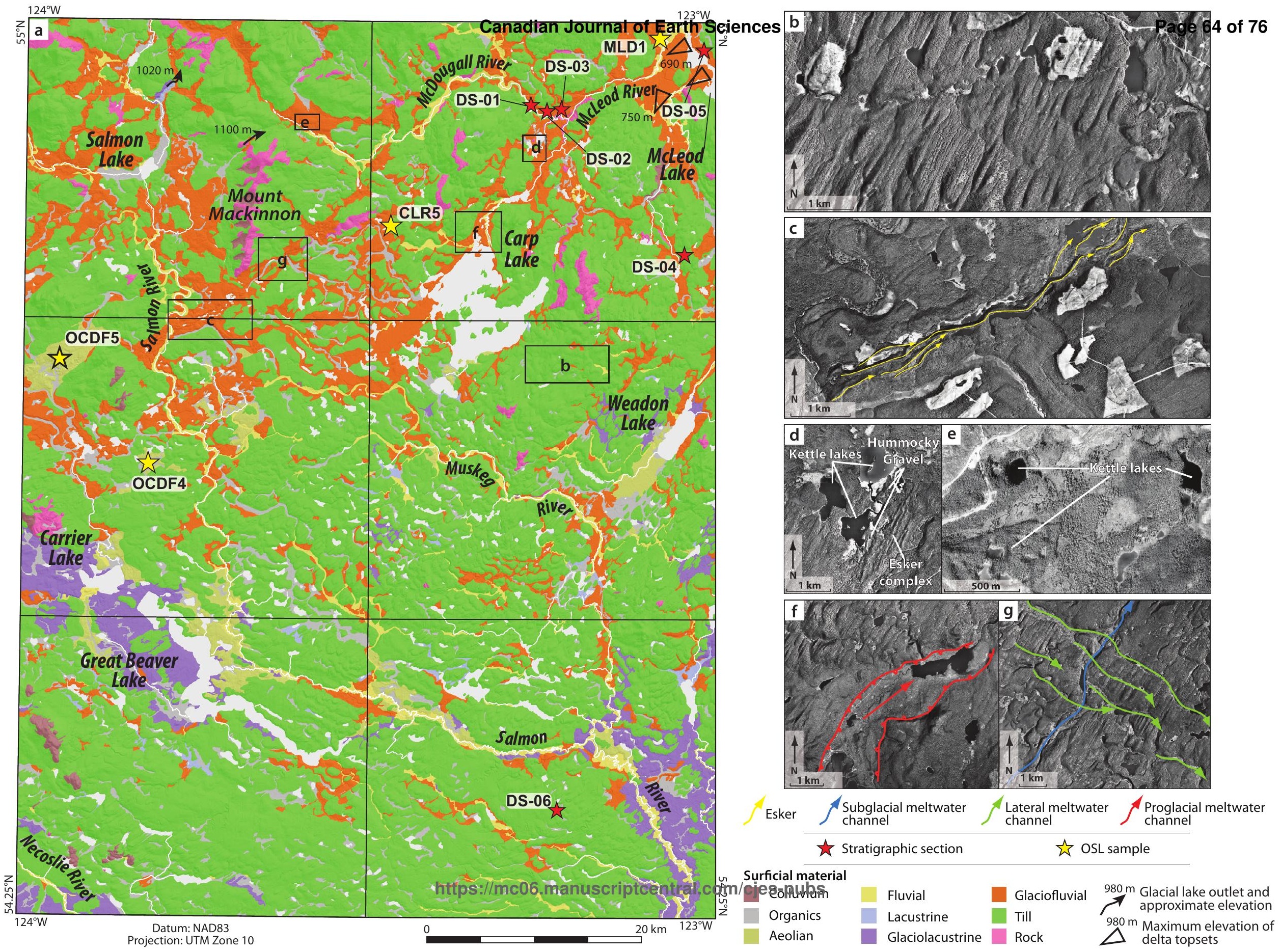



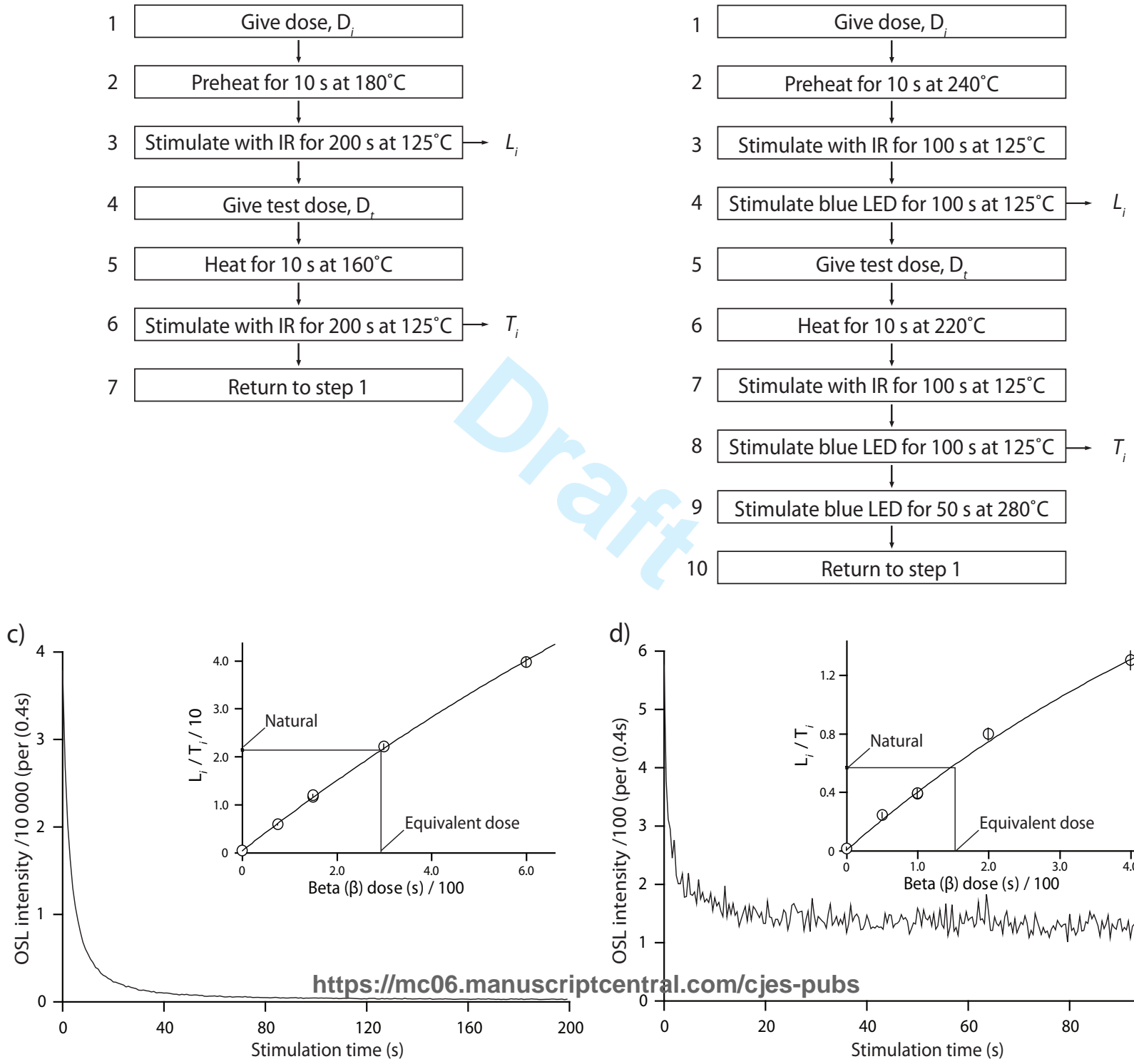

d)

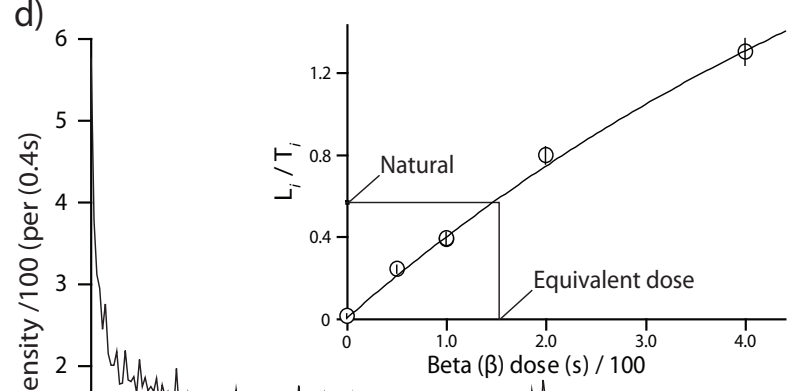

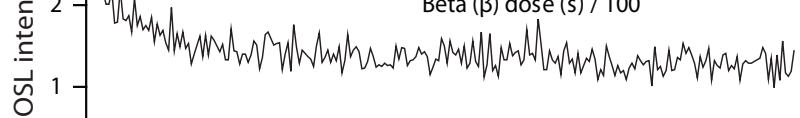

ntral.com/cjes-pubs

Stimulation time $(\mathrm{s})$

$\begin{array}{cccc}1 & 1 & 100 \\ 40 & 60 & 80 & 100 \\ \text { Stimulation time }(\mathrm{s}) & & \end{array}$




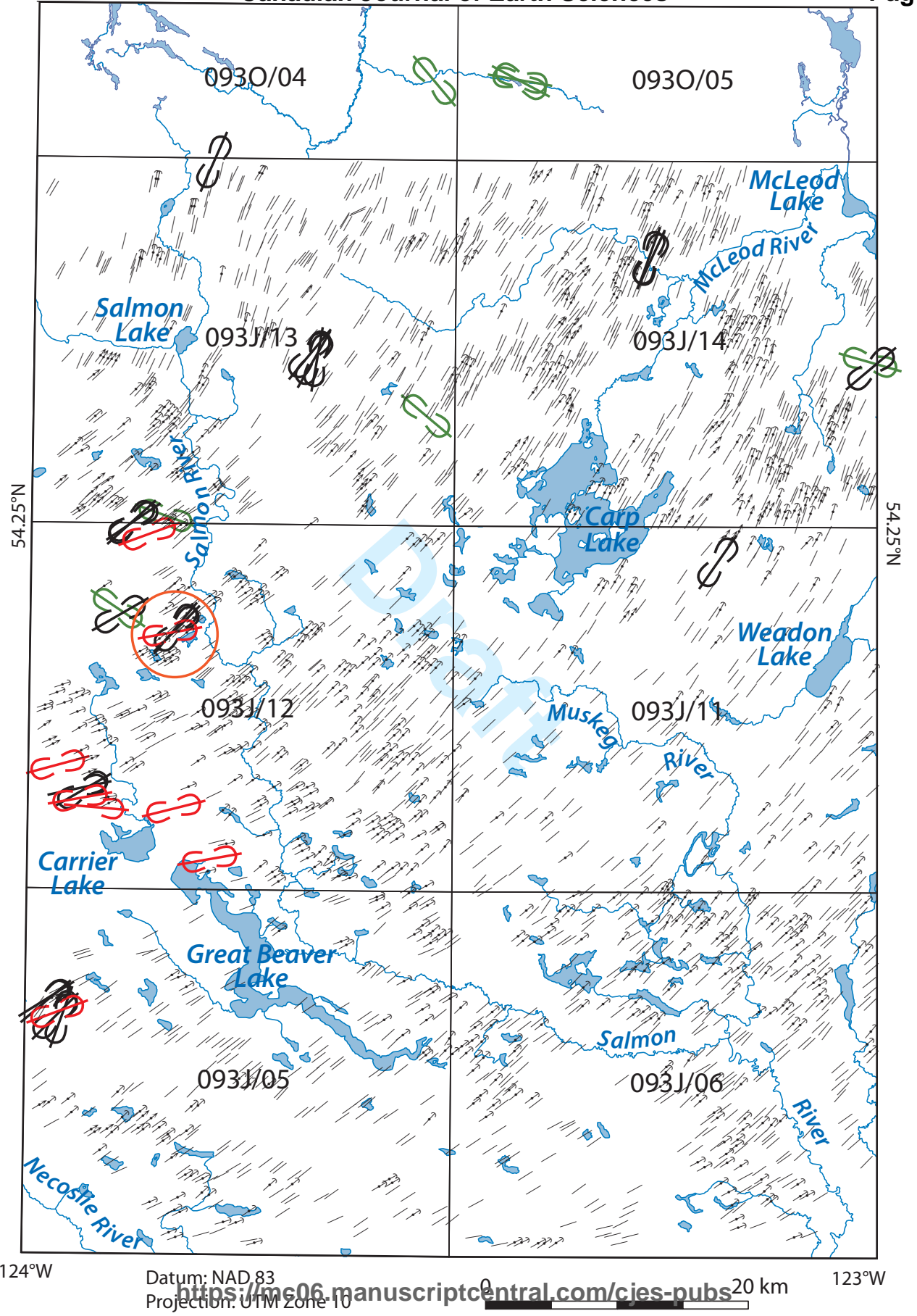

$\not \mathscr{Q}$ Striation (direction known; unknown) $\Rightarrow$ Drumlin $\quad /$ Fluting $\&$ Crag and tail 


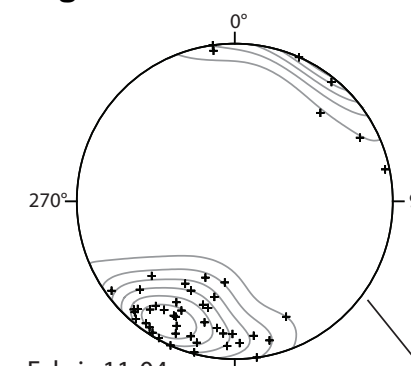

Fabric 11-04 $180^{\circ}$

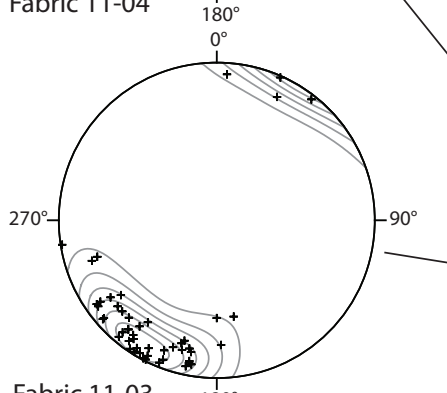

Fabric 11-03 $180^{\circ}$

Fabric 10-02 $180^{\circ}$

\section{Page 69 of $76 \quad$ Fabric $09-0$ Canaidian JournalFoffi Eq9rth Sciences \\ Page 69 of $76 \quad$ Fabric $09-0$ Canaidian JournalFoffiEgrrfh Sciences}
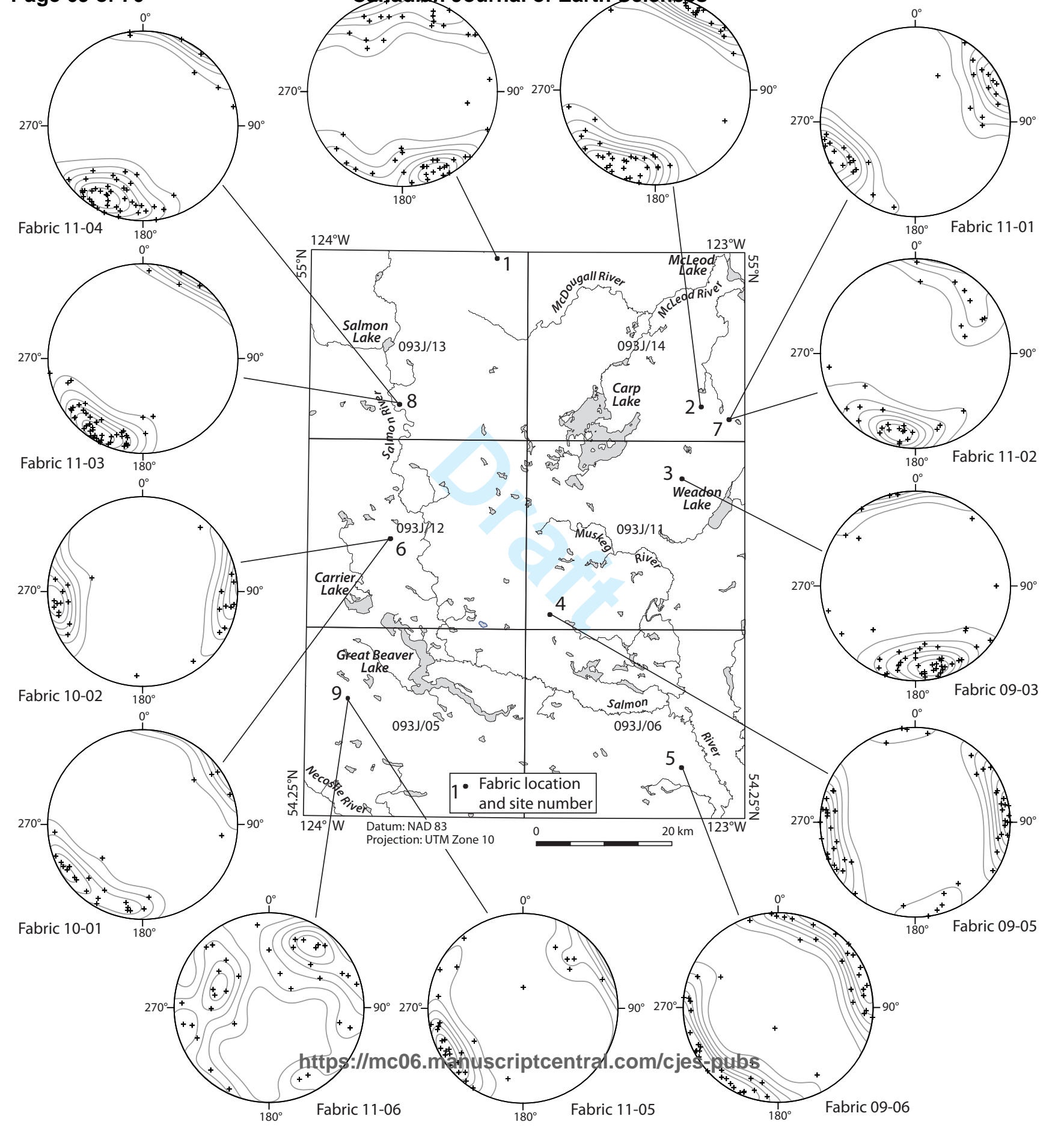


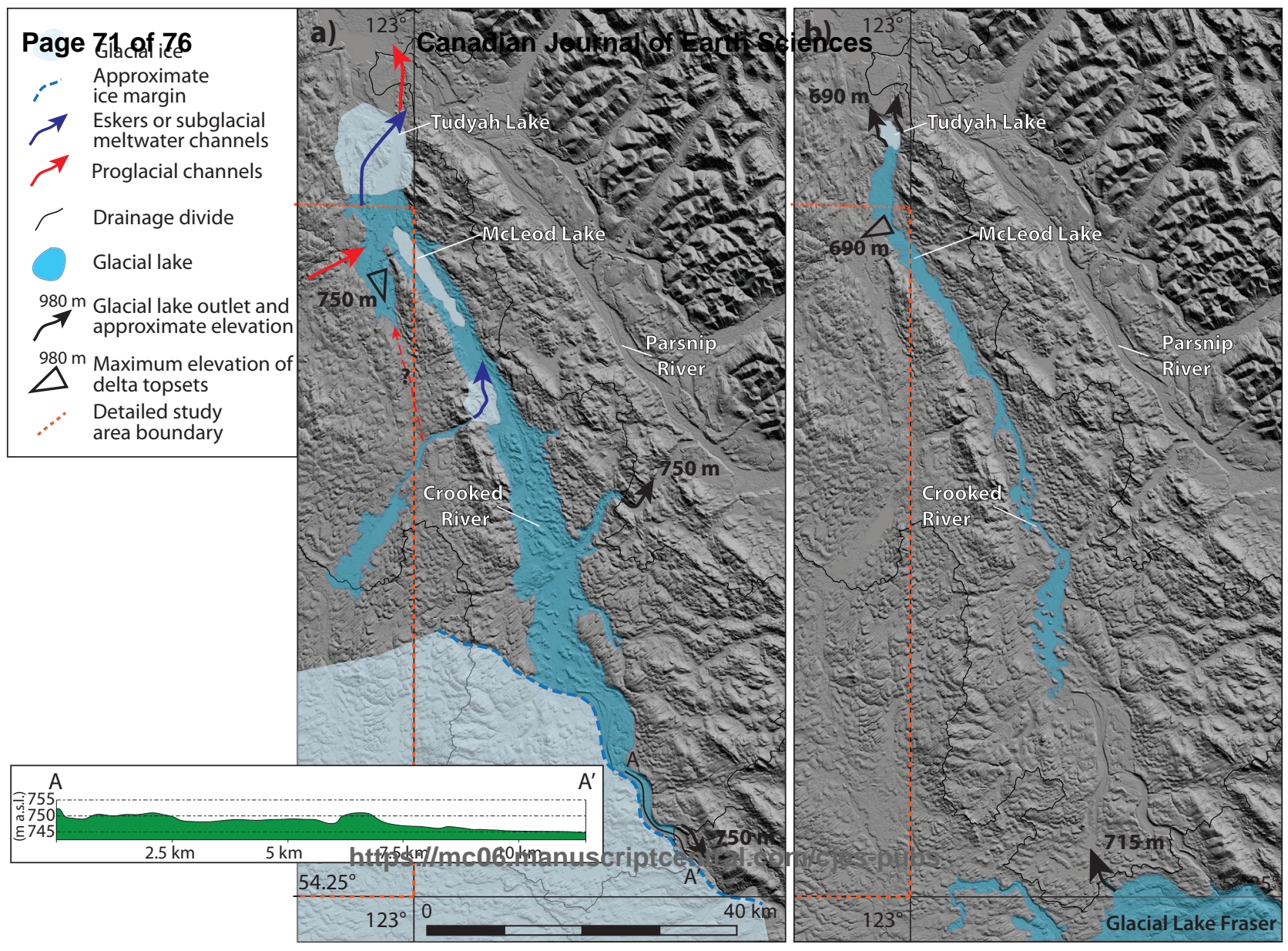

\section{Page Z17agfize}

,- Approximate

- ice margin

7 Eskers or subglacial meltwater channels

7 Proglacial channels

$\ulcorner$ Drainage divide

- Glacial lake

$980 \mathrm{~m}$ Glacial lake outlet and 7 approximate elevation

$980 \mathrm{~m}$ Maximum elevation of $\triangle$ delta topsets

Detailed study area boundary

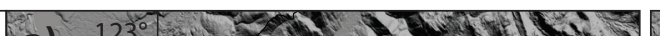

更 750

750

$2.5 \mathrm{~km}$

$5 \mathrm{~km} \quad \mathrm{htt7}$. $\mathrm{dkm} / \mathrm{mc060 \textrm {kmanus }}$

$54.25^{\circ}$

$123^{\circ}$
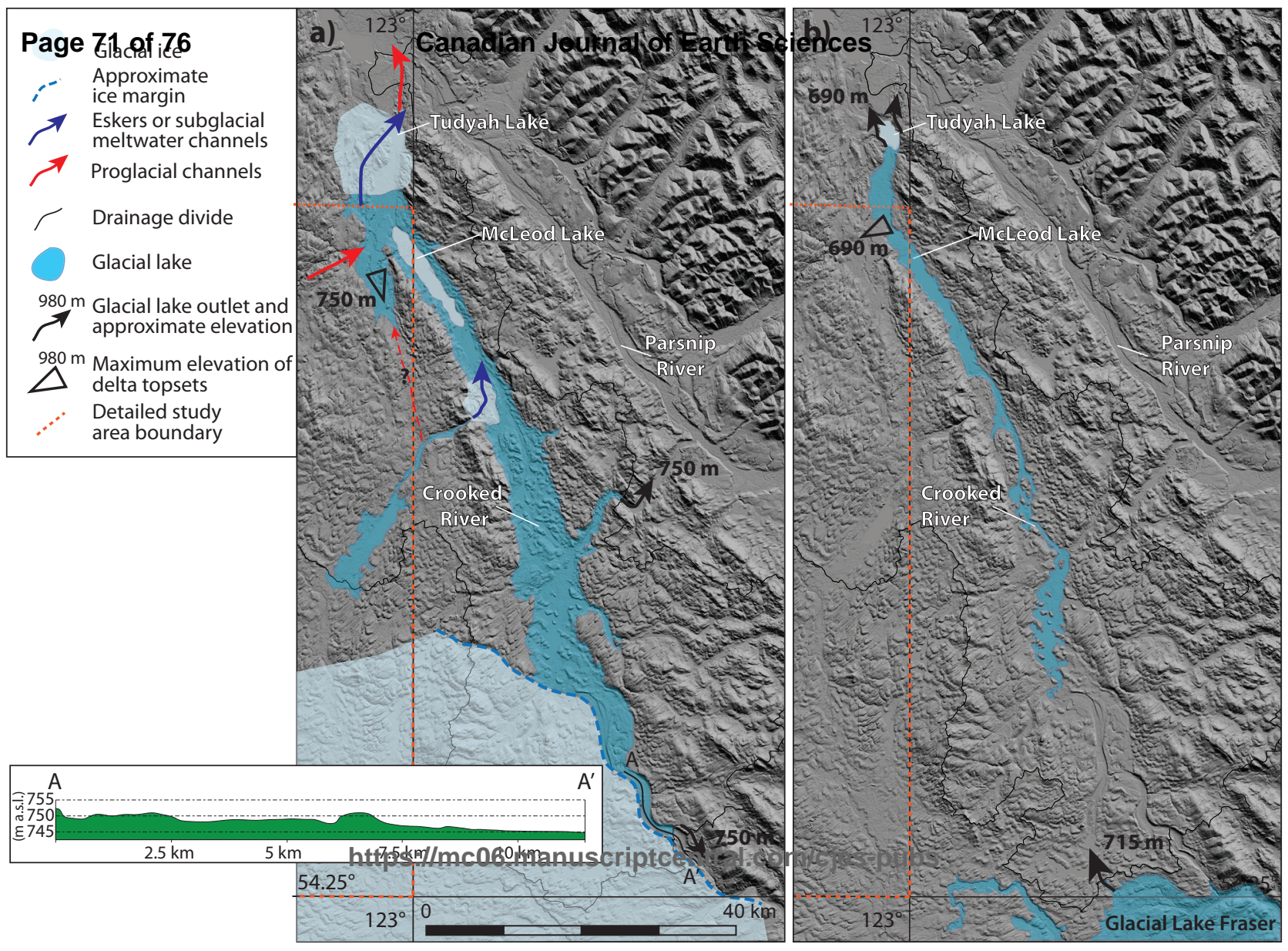


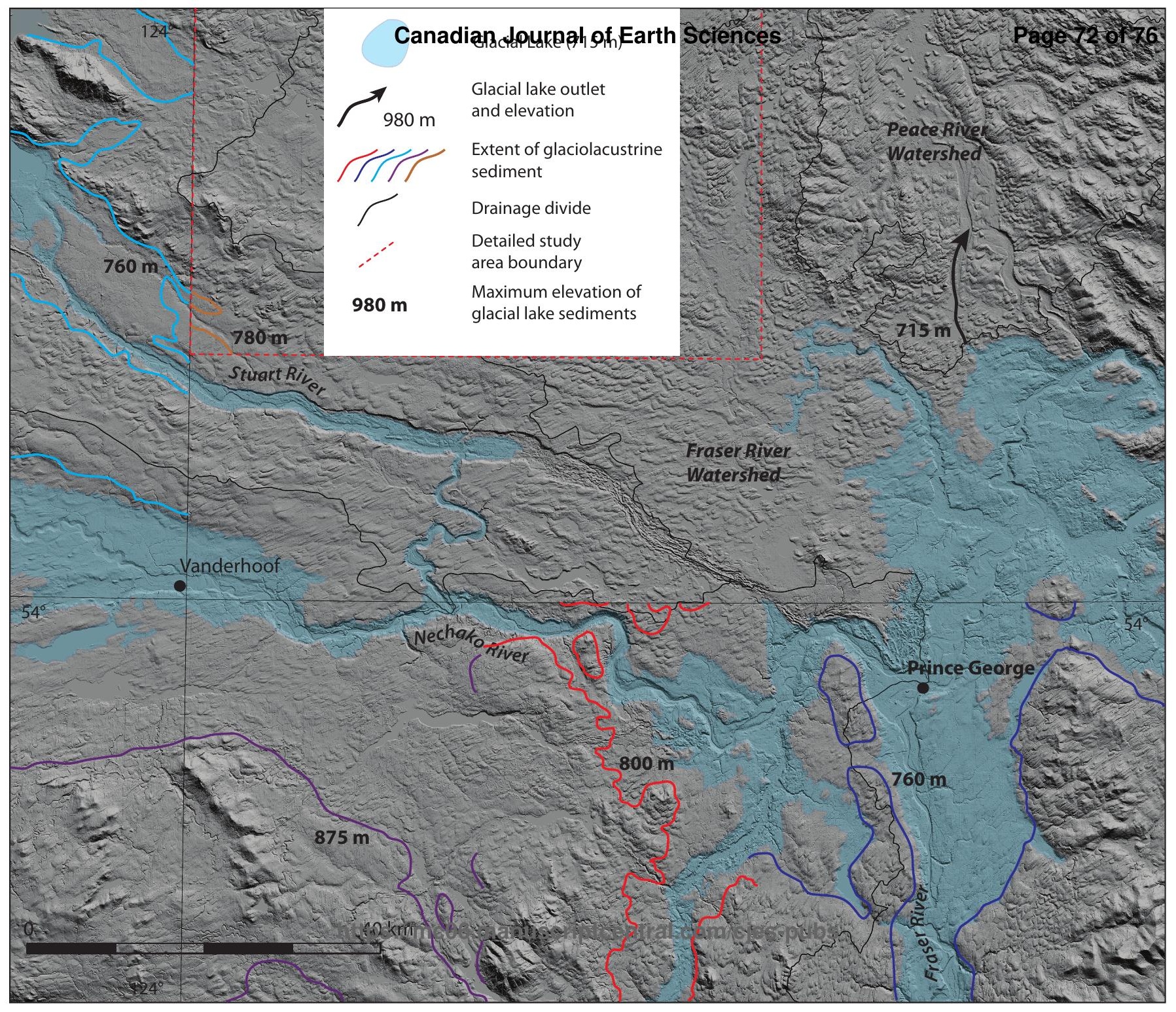



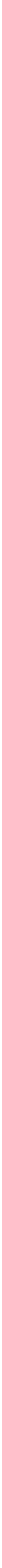

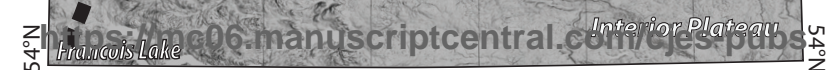

Datum: NAD 83

Projection: PC Albers

$50 \mathrm{~km}$ 
1

2

Give dose, $\mathrm{D}_{i}$

3 Stimulate with IR for $200 \mathrm{~s}$ at $125^{\circ} \mathrm{C} \longrightarrow L_{i}$

4

Give test dose, $\mathrm{D}_{+}$

5

Heat for $10 \mathrm{~s}$ at $160^{\circ} \mathrm{C}$

6 Stimulate with IR for $200 \mathrm{~s}$ at $125^{\circ} \mathrm{C} \longrightarrow T_{i}$

$7 \quad$ Return to step 1
1

Give dose, $\mathrm{D}_{i}$

2

Preheat for $10 \mathrm{~s}$ at $240^{\circ} \mathrm{C}$

3 Stimulate with IR for $100 \mathrm{~s}$ at $125^{\circ} \mathrm{C}$

4

Stimulate blue LED for $100 \mathrm{~s}$ at $125^{\circ} \mathrm{C} \longrightarrow L_{i}$

5

Give test dose, $\mathrm{D}_{t}$

6

Heat for $10 \mathrm{~s}$ at $220^{\circ} \mathrm{C}$

7 Stimulate with IR for $100 \mathrm{~s}$ at $125^{\circ} \mathrm{C}$

$\downarrow$

8

Stimulate blue LED for $100 \mathrm{~s}$ at $125^{\circ} \mathrm{C} \longrightarrow T_{i}$

9

Stimulate blue LED for $50 \mathrm{~s}$ at $280^{\circ} \mathrm{C}$

10

Return to step 1

C)

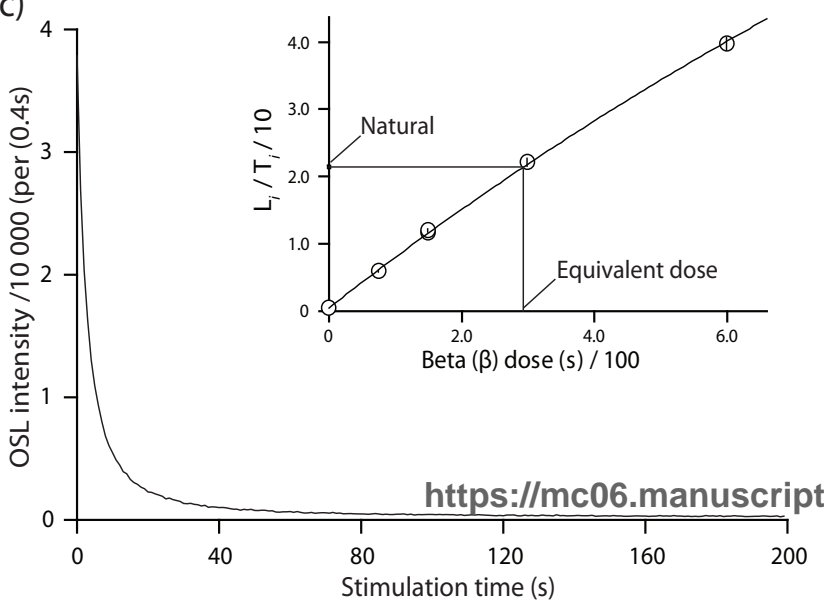

d)

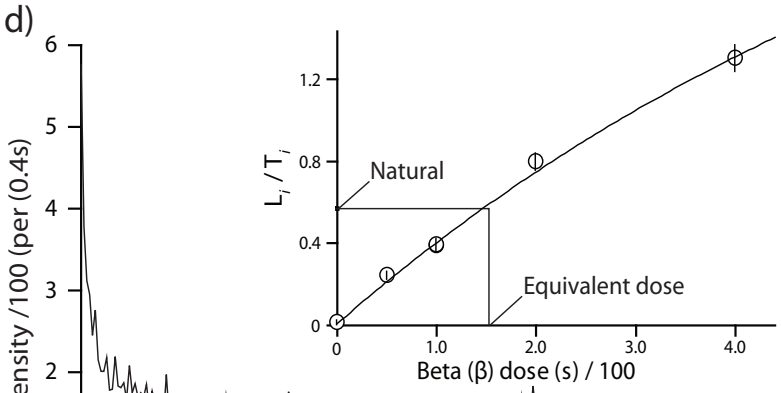
$\stackrel{\text { जू. }}{\stackrel{ \pm}{\Xi}} 1$ -

$\begin{array}{cccccc}0 & 1 & & & \\ 0 & 20 & 40 & 60 & 80 & 100 \\ & & \text { Stimulation time (s) } & & \end{array}$




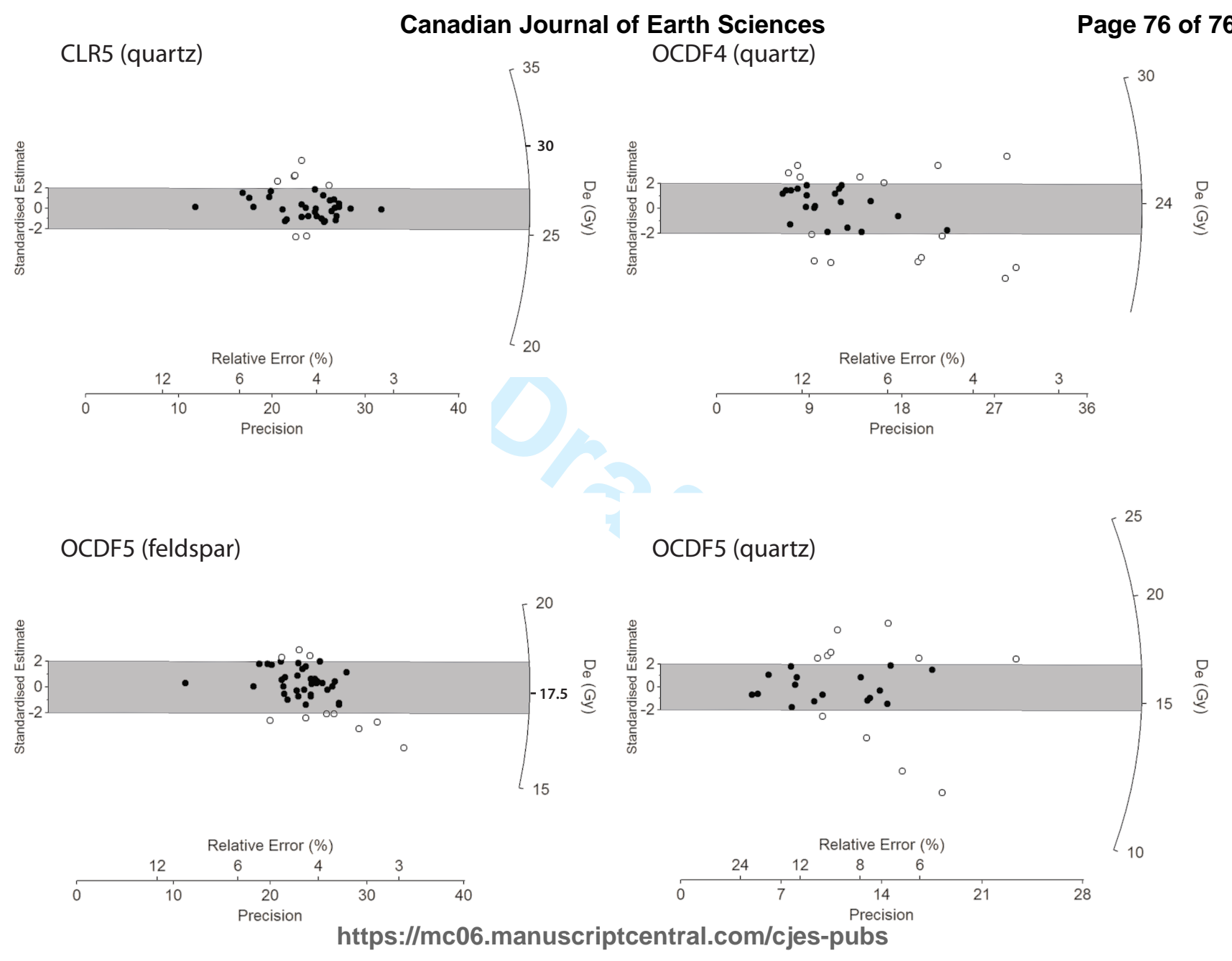

